\title{
Liberdade, alienação e criação literária: reflexões sobre o homem contemporâneo a partir do existencialismo Sartriano
}

\section{Freedom, alienation and literary creation: considerations on the contemporary man from the perspective of Sartrean existentialism}

\section{Amana Rocha Mattos*}

Universidade do Estado do Rio de Janeiro - UERJ, Rio de Janeiro, Rio de Janeiro, Brasil

\section{Ariane Patrícia Ewald**}

Universidade do Estado do Rio de Janeiro - UERJ, Rio de Janeiro, Rio de Janeiro, Brasil

\section{Fernando Gastal de Castro***}

Universidade Federal do Rio de Janeiro - UFRJ, Rio de Janeiro, Rio de Janeiro, Brasil

\begin{abstract}
RESUMO
O presente artigo reúne reflexões a respeito de três diferentes temas da contemporaneidade, tendo como referencial comum o pensamento do filósofo francês Jean-Paul Sartre. O artigo inicia com a discussão sobre os sentidos de liberdade que são compartilhados em nossa sociedade atual; em seguida, discute as relações de trabalho na contemporaneidade que isolam o homem no produtivismo serial; e por fim, elabora uma reflexão sobre o status do imaginário e sua relação com o mundo da vida, a literatura e a ciência. A discussão dessas temáticas é feita tendo como pano de fundo os aspectos sócio-históricos e filosóficos do surgimento e consolidação da modernidade, pensados sob o ponto de vista da ideia de liberdade sartriana. Palavras-chave: Liberdade, Alienação, Imaginário, Existencialismo, JeanPaul Sartre.
\end{abstract}

\begin{abstract}
This paper presents the discussion on three different themes related to contemporaneity, having as common referential the thought of the French philosopher Jean-Paul Sartre. The paper initiates with the discussion on the meanings of freedom that are shared in our society; then, it duscusses the contemporary work relations that isolate men in serial productivism; finally, it brings a reflexion on the status of the imaginary and its relation with the world of life, literature and science. The background of these discussions are the social, historical and philosophical aspects of the upcoming and consolidation of Modernity, considered by the perspective of the Sartrean idea of freedom.

Keywords: Freedom, Alienation, Imaginary, Existentialism, Jean-Paul Sartre.
\end{abstract}




\section{Introdução}

Este texto é resultado de um trabalho conjunto, o qual vem sendo desenvolvido por nós desde 2011. Ministramos conjuntamente uma disciplina no Programa de Pós-Graduação em Psicologia Social/UERJ, a qual resultou numa mesa redonda no "IV Congresso LatinoAmericano de Psicoterapia Existencial e Enfoques Afins", em novembro de 2011 na UERJ. A iniciativa de realizarmos estes trabalhos em conjunto está diretamente ligada não apenas à nossa afinidade teórica mas,também, à nossa visão crítica sobre as questões que mobilizam a subjetividade e a psicologia no mundo contemporâneo.

É fundamental esclarecer que optamos por construir um texto em que cada um trabalhasse suas reflexões dentro do tema que nos aproximou, o qual transformamos em título para este artigo.

sentido, procuramos montar o texto na sequência que consideramos mais coerente para o leitor e que reproduzisse, em parte, a trajetória de nossas discussões, tanto na disciplina da pós quanto na mesa redonda no congresso. Dessa forma, apresentamos reflexões a respeito de três diferentes temas que têm como horizonte comum aos autores, o pensamento do filósofo francês Jean-Paul Sartre. 0 artigo é iniciado com a discussão sobre os sentidos de liberdade que são compartilhados em nossa sociedade atual; em seguida, discute as relações de trabalho na contemporaneidade que isolam o homem no produtivismo serial; e por fim, elabora uma reflexão sobre o status do imaginário e sua relação com o mundo da vida, a literatura e a ciência. A partir de diferentes referenciais teóricos, a discussão dessas temáticas é feita tendo como pano de fundo os aspectos sócio-históricos e filosóficos do surgimento e consolidação da modernidade, pensados sob o ponto de vista da ideia de liberdade sartriana.

No primeiro item, Amana Mattos faz a revisão da ideia de liberdade difundida em nossa sociedade contemporânea, pensando como essa noção traz elementos próprios do liberalismo - corrente teórica e política que se consagrou como um pensamento hegemônico ao longo do século XX nas ciências humanas, economia e filosofia. São levantados alguns problemas que a difusão dessa ideia no imaginário e nas práticas sociais acarreta, como a valorização extrema do individualismo, a privatização do exercício da liberdade e a despolitização dessa noção. Para essa discussão, as contribuições de Sartre são cruciais. Ao criticar a liberdade liberal como exaltação da escolha individual, o filósofo destaca o aspecto intersubjetivo da ação livre, o que torna questionável a concepção de liberdade como atributo e direito do indivíduo. Sartre discute ainda a dimensão inerradicável de alteridade da liberdade, o que implica a imprevisibilidade do ato livre, por um lado, e a necessidade de 
engajamento e responsabilização do sujeito no exercício de sua liberdade, por outro.

No segundo item, Fernando de Castro aborda as noções de liberdade como "livre praxis" e objetivação da subjetividade, o que nos permite pensar a alienação como liberdade alienada. Em seguida, desenvolve a ideia de uma "ascensão do domínio do prático inerte", abordando três formas sócio-históricas definidas de organização do trabalho, diretamente ligadas ao crescimento da alienação. São essas ${ }^{1}$ a burocracia, com seu correlato antropológico que é o homem adaptado à norma, ${ }^{2}$ o taylorismo, com seu correlato antropológico caracterizado pelo homem máquina, $\mathrm{e}^{3} \mathrm{o}$ new management e a teoria do 'capital humano', com seu correlato antropológico constituído pelo homem hiperativo. Em cada uma dessas formas sócio-históricas, é possível encontrar um crescimento do campo prático inerte dominando as possibilidades individuais. O ponto comum dessas três formas sócio-históricas de organização social do campo prático inerte é a «negação da liberdade», em função de uma pretensa razão universal apoiada num racionalismo cientificista que altera a autonomia em heteronomia. Em seguida, analisa a especificidade do momento sócio-histórico atual caracterizado por um domínio da impotência e da solidão serial em função de um realidade social paradoxal. O new management, ao fazer apelo tanto a uma lógica existencial de engajamento pessoal quanto a um homem hiperprodutivo e individualista, cria um impasse entre a possibilidade de construção de si mesmo e a possibilidade de construção do ser social, onde o suicídio, ligados às condições de trabalho nos dias atuais, pode se revelar como o ápice da alienação vista como liberdade-alienada.

Finalmente, no último item, Ariane Ewald discute a noção de imaginário e a literatura como campo de investigação e criação, o que nos leva a uma reflexão sobre o processo de construção da escrita em pesquisas e, consequentemente, sobre as publicações resultantes das mesmas. A Literatura desde muito cedo para Sartre, constitui-se como fonte de questionamento sobre a condição humana e também como modo de expressão de suas ideias. Em seus primeiros textos publicados, nos anos 1930, ele ensaia suas inquietações filosóficas de forma acadêmica e, ao mesmo tempo, em expressão artística: $A$ Náusea é seu mais belo exemplar. O resultado deste procedimento rendeu-Ihe notoriedade como escritor e ele compreendeu que as duas formas de expressão podiam caminhar conjuntamente, cada uma explorando suas próprias facetas, sem perderem fôlego nem profundidade.

Tomando esta relação entre estes modos de expressão tão diferentes como ponto de partida, este item procura discutir como a Literatura se constitui como espaço de reflexão sobre a vida e também como campo de trabalho para a Psicologia Social, tendo a noção de 
imaginário como ponto fundamental para compreendermos que a ciência é também processo de criação e que o imaginar faz parte dos "procedimentos" acadêmicos em todos os sentidos.

Com este artigo, pretendemos iluminar algumas questões contemporâneas - liberdade, trabalho, literatura - a partir das contribuições de Jean-Paul Sartre. Ao visitarmos esses temas sob a perspectiva do filósofo francês, a atualidade da obra sartriana se revela como uma importante aliada para discutirmos questões tão caras à psicologia.

\section{Contribuições de Jean-Paul Sartre para pensarmos a liberdade na contemporaneidade: uma crítica à ideia de liberdade liberal}

A ideia de liberdade que circula em conversas e debates, que é vivida e sentida como dimensão importante da vida pessoal, que aparece como valor prezado nas relações e nos vínculos contemporâneos, não surge espontaneamente no cotidiano e no pensamento das pessoas. Como um problema caro às ciências políticas e à filosofia, a história do conceito de liberdade se mistura com a própria história da modernidade. Objeto de grandes disputas teóricas e de poder, a ideia de liberdade tem uma trajetória que percorre as principais escolas e domínios da filosofia e das ciências humanas.

No que se refere a essa discussão, uma das correntes teóricas mais importantes das ciências políticas e da economia é, certamente, o liberalismo. Desde seu surgimento revolucionário, na luta da burguesia contra o poder soberano dos monarcas no contesto do Iluminismo, até os dias atuais, marcados pela economia de mercado e pela hipertrofia das liberdades individuais, é possível identificar elementos na teoria liberal que forjaram uma noção muito específica de liberdade que está amplamente difundida em nossa sociedade hoje.

Neste subitem, apresentaremos a noção de liberdade liberal que vem se difundindo em nossa sociedade para, em seguida, desenvolvermos as críticas que Sartre teceu a essa acepção de liberdade, deslocando - centro da questão da liberdade de escolha individual para o problema da existência e das relações intersubjetivas.

\subsection{A ideia de liberdade hoje e a valorização do indivíduo}

A liberdade surge como um valor central em nossa sociedade. Vem sendo experienciada no último século numa acepção bem particular, marcada por questões que são próprias do contemporâneo, como o individualismo, a competitividade, o consumo e o desenraizamento dos indivíduos. Ainda que essas questões se encontrem acirradas e 
em destaque na contemporaneidade, é possível traçar sua continuidade com temas que vêm sendo pensados desde 0 surgimento da modernidade. Esse é o caso da ideia de sujeito, que emerge com os autores iluministas da filosofia e das ciências sociais que tematizaram o poder e as relações entre homens e Estado, exaltando a necessidade de emancipação de fato e de direito dos homens em relação ao poder despótico do Rei, e trazendo o elogio de uma racionalidade encarnada no cidadão.

Entre os pensadores que discutiram o governo democrático ou, ao menos, a necessidade de que o monarca não governasse acima da lei dos homens, percebemos a conexão da noção de sujeito racional, autônomo, capaz de introspecção, com a noção de indivíduo comum, que tem seus interesses próprios e que vive num Estado moderno regido por convenções e leis, feitas pelos homens e para os homens. É o caso de John Locke que, no final do século XVII, toma a ideia de contrato apresentada por Thomas Hobbes, pensando-a como um acordo feito por homens livres e racionais visando a fundação de um poder limitado que os governasse. Com isso, Locke tira o poder de governar a sociedade da esfera religiosa e despótica, tratando esse poder como uma concessão de todos e de cada um dos homens para que a vida em sociedade seja possível.

Seguindo as discussões dos autores fundamentais para o liberalismo, especialmente daqueles que constituíram as bases do pensamento que orientou a Revolução Francesa (Jean-Jacques Rousseau, Thomas Hobbes), poderíamos supor que a constituição do cidadão livre das sociedades democráticas deveu-se à difusão das ideias da filosofia iluminista. A afirmação de Voltaire, em pleno século XVIII, no auge do Iluminismo, denota claramente o projeto de formação e esclarecimento do homem: "No essencial, em sua acepção mais apropriada, a ideia de liberdade coincide com a dos direitos do homem. O que quer dizer, finalmente, ser livre senão conhecer os direitos do homem? Pois conhecê-los é defendê-los." (VOLTAIRE apud CASSIRER, 1997, p. 336; grifos do autor). Consolida-se, assim, a importância da autonomia e da independência para que os cidadãos pudessem participar politicamente da sociedade.

Teóricos do liberalismo concordam que o movimento passou por diferentes fases relacionadas ao contexto político-econômico europeu e mundial. A Declaração Americana da Independência e a Revolução Francesa lançaram as bases para os Direitos Universais do Homem, compreendendo as noções de liberdade individual e igualdade entre os sujeitos. Os pensadores liberais dessa época criticavam a centralização do poder no Estado monárquico e a limitação das liberdades civis. Mas é com o advento da economia industrial, na segunda metade do século XIX, que as ideias liberais se firmaram no panorama mundial e as conquistas do liberalismo se efetivaram: 
liberdade religiosa, direitos humanos, um governo representativo responsável e a legitimação da mobilidade social (MERQUIOR, 1991). Para Kolm (1984), o liberalismo é o pensamento político e econômico da modernidade por excelência, por trazer em sua proposta todos os elementos que são caros ao mundo moderno:

\begin{abstract}
O liberalismo se justifica, de princípio, pela liberdade. Depois, pelo bem-estar e pela eficácia econômica que a liberdade econômica sem entraves acarreta. Liberdade e bem-estar promovem a felicidade. $E$, fundamentalmente, o liberalismo econômico repousa sobre o individualismo e o respeito ao Direito, e, em particular, à propriedade individual. Ora, esses são os valores que se diz mais fortes e mais gerais no mundo moderno. (KOLM, 1984, pp. 11-12)
\end{abstract}

Vemos definir-se na contemporaneidade uma ideia difundida de liberdade que foi consolidando-se em torno da valorização da independência individual. A defesa da liberdade de escolha e de decisão, a ser realizada no plano individual, é sua principal marca. Trata-se de uma liberdade que prioriza a liberação do indivíduo de obstáculos externos, empecilhos que se coloquem entre o indivíduo e a realização de seus desejos e projetos. Esse sentido de liberdade, recorrente na teoria liberal, define-se pelo que o filósofo Isaiah Berlin chamou de "liberdade negativa", isto é, a situação em que o indivíduo é mais livre quanto menos impedimentos se coloquem em seu caminho, em suas ações (BERLIN, 2002).

Uma das consequências mais perceptíveis de tal acepção de liberdade é a privatização de seu exercício. A prática da liberdade, a ação livre, passa a ser algo que concerne à esfera privada, ao indivíduo, e em condições ideais deve sofrer o mínimo possível de regulação exterior (seja vinda de outros indivíduos, de outros grupos, ou do Estado). É o que destaca Benjamin Constant, pensador liberal francês, já em 1815, em seu importante texto "Da liberdade dos antigos comparada à dos modernos" (CONSTANT, 1985 [1815]). Nesse texto, o autor compara a liberdade valorizada na modernidade então emergente, que ressalta a primazia do indivíduo, sua preocupação com a vida e os interesses privados, com a liberdade exercida na polis da Grécia Antiga. Na liberdade dos antigos, haveria uma busca pela igualdade entre os cidadãos, pois esta, somada à liberdade, seriam a pré-condição para o exercício da política na esfera pública - atividade mais nobre a que um cidadão da polis poderia almejar.

Como desdobramento do efeito de privatização da liberdade no mundo moderno, muitos autores vão destacar que ocorre uma despolitização do exercício da liberdade. Uma vez que a liberdade passa a ser algo que diz respeito à realização, à felicidade e aos interesses particulares dos indivíduos, afastando-se de questões 
relacionadas ao mundo coletivo, público, comum, a ação livre tornase um prazer e uma conquista do indivíduo independente. Todos querem ser livres, e para que isso seja plenamente buscado (mas não necessariamente alcançado), impõe-se um afastamento completo de questões públicas. Como bem resumiu Hannah Arendt, o mundo moderno reitera a convicção liberal de que "quanto menos política, mais liberdade" (ARENDT, 1972). Para que os interesses individuais sejam defendidos na esfera pública, a modernidade aposta na democracia representativa: alguns políticos profissionais se dedicam às questões que dizem respeito à sociedade como um todo, enquanto os cidadãos comuns se liberam para viverem suas vidas privadas e buscarem a felicidade individual.

\subsection{A liberdade em Sartre e o problema da intersubjetividade}

Tendo feito esta breve introdução sobre como, na modernidade, a ideia de liberdade destaca-se hegemonicamente por sua acepção liberal, gostaríamos agora de trazer algumas contribuições feitas por Sartre a esse tema, destacando as críticas feitas pelo autor à perspectiva liberal de liberdade como exercício individual da escolha e da independência, e expondo seus principais argumentos para pensarmos a liberdade implicada constitutivamente na intersubjetividade.

Para os autores liberais, ser livre é um direito a ser exercido e configura-se como um valor na sociedade, capaz de trazer a felicidade e a realização pessoal aos cidadãos. Acontece que a ação livre é, muitas vezes, acompanhada por sentimentos que não correspondem a essa realização pessoal que preconiza a teoria liberal. Ao contrário, o agir livre leva constantemente os sujeitos a se depararem com o mal-estar, com conflitos, com a angústia. A liberdade pode paralisar os sujeitos, levando-os a dilemas éticos e a pensamentos inquietantes. Essa dimensão constitui parte do exercício da liberdade, e precisa ser pensada a partir de outro referencial teórico que não apenas o das teorias liberais individualizantes, posto que estas não priorizam dois aspectos cruciais da liberdade: a relação com o outro e a dimensão do conflito.

Ao longo de sua obra, Sartre propõe que a liberdade seja pensada como uma experiência constitutiva da ação humana. Em suas críticas mais contundentes ao pensamento liberal, Sartre define a "livre escolha" do liberalismo como uma escolha que se realiza entre opções já dadas, que negligencia a reflexão do sujeito sobre como encaminhar sua vida, sobre quais opções são válidas para serem objeto de escolha, e quais não. Essas seriam reflexões que provocariam a angústia no exercício da liberdade. Esse sentimento não discutido pela teoria liberal aparece, no existencialismo, quando o sujeito toma consciência de que pode mudar sua ação (seus 
valores), pois esta é resultado de sua liberdade, ou, melhor dizendo, sua ação é sua liberdade. Isso significa dar-se conta de que o conjunto de possíveis que aparecem diante de si quando um sujeito está em situação de escolha é produzido pela condição desse sujeito no mundo, na qual ele está intimamente implicado. As possibilidades de escolha não são, para Sartre, dadas de saída, mas são colocadas pelo sujeito a partir de seus valores, de sua posição no mundo, do que o autor chama de seu projeto. Opções que se colocam claramente para alguns sujeitos não são sequer cogitadas por outros que se encontram na mesma circunstância. É conhecida a frase de Sartre em $O$ Ser e o Nada a esse respeito: "Quando delibero, os dados já estão lançados." (SARTRE, 2007, p. 557)

Além de relacionar as opções que aparecem numa escolha ao exercício da liberdade, Sartre enfatiza que o fato do sujeito efetivar sua escolha não dissipa as demais opções. Isso ocorre porque elas têm relação com as questões que o próprio sujeito se coloca em sua vida, estando ligadas à sua vivência e seus valores. Escolher entre opções possíveis apenas evidencia um caminho que está sendo tomado, mas não faz com que as opções restantes sejam completamente alheias ao sujeito a partir da escolha feita. Como afirma Barata, ao comentar o conceito de liberdade em Sartre,

\section{[...] trata-se de dar conta do facto de que não há realmente uma capacidade, por parte do sujeito que sustenta uma escolha, de eliminar as alternativas de escolha preteridas. [...] O que eu decido não deixa, por ter sido decidido, de permanecer apenas uma possibilidade entre outras possibilidades. (BARATA, 2005)}

Essa característica da liberdade humana, de ser sempre uma realização de possíveis, faz com que o sujeito tenha que lidar com o fato de que suas escolhas poderiam ter se dado de outra maneira. Além disso, o filósofo enfatiza o quanto os sujeitos estão concernidos nos rumos que suas vidas tomam, mesmo que eles os atribuam a eventos independentes de sua vontade. Nesse sentido, Sartre quer trazer a discussão da liberdade para o campo da responsabilização, da implicação, ainda que isso não signifique, de maneira alguma, que o sujeito tenha domínio dos efeitos provocados por seu agir livre.

No que diz respeito à maneira como a filosofia moderna lida com a temática da liberdade - profundamente inspirada pelos autores iluministas e liberais -, Sartre chama atenção para o fato de que os realistas (filósofos e cientistas humanos que tomam a realidade como dada, como uma evidência) nunca se preocuparam efetivamente com o problema do outro ao pensarem a natureza humana, tomando o outro como um dado, assim como os demais fenômenos da natureza. No estudo realista sobre o outro, feito pela psicologia positivista, por exemplo, 
[a] hipótese que melhor explica o comportamento do outro é a de uma consciência análoga à minha, cujas diferentes emoções nele se refletem. [...] a maioria dos psicólogos permanece convictos da existência do outro como realidade totalitária de estrutura idêntica à sua. Para eles, a existência do outro é certa, e provável o conhecimento que temos dela. (SARTRE, 2007, p. 292-293)

Assim, a tradição realista do conhecimento pensa o sujeito como dado, e o outro é entendido como uma duplicação do sujeito. Na psicologia positivista, o estudo dos indivíduos se dá através da observação de seu comportamento e desenvolvimento, entendidos como equivalentes (ou análogos) em todos os casos. O outro é mais um indivíduo.

Sartre afirma ainda que, no que diz respeito ao idealismo, o estudo da pessoa não é uma prioridade, pois autores como Kant ou Spinoza, estão preocupados em estabelecer as "leis universais da subjetividade", no primeiro caso, ou a "essência do homem", no segundo, perdendo-se a questão da pessoa concreta: "tanto para o idealista como para o realista, impõe-se uma conclusão: pelo fato de que o outro nos é revelado em um mundo espacial, é um espaço real ou ideal que nos separa do outro." (SARTRE, 2007, p. 301).

As correntes idealistas e realistas são dominantes na filosofia ocidental. Sartre, assim como os demais existencialistas, está implicado em denunciar que esse projeto de conhecimento não deixa lugar para a existência, para o homem no mundo. Ao falar do espaço que separa o sujeito do outro, tradicionalmente pensado pela filosofia como real ou ideal, Sartre toca em um ponto que nos remete ao problema dos limites da liberdade: na tradição realista (empirista, positivista, da qual decorre a teoria liberal), o espaço em que a liberdade e, principalmente, seus limites se dão é o espaço empírico, observável. O conceito de liberdade negativa na teoria liberal exprime essa natureza do espaço: liberdade de ir e vir, de se expressar, de não sofrer coerções. Já na tradição idealista, a liberdade está relacionada à ideia de autonomia, de regras estabelecidas pelo próprio sujeito para orientarem sua conduta moral. O espaço em que a liberdade e a falta de liberdade se dão é o espaço ideal - o espaço do pensamento racional. Erguer uma máxima para si mesmo e agir segundo essa máxima, de tal maneira que sua ação seja válida para todos, é o imperativo categórico kantiano que melhor define o conceito de autonomia. A universalidade é o domínio, por definição, do exercício da liberdade enquanto autonomia.

O grande problema silenciado nessas duas tradições é a questão do outro. Não do outro tomado como igual, semelhante, cujas necessidades, motivações e capacidades se equivalem às minhas. Nem do outro enquanto encarnação do sujeito racional, assim como o 
próprio sujeito livre. Mas do outro que desconheço, que não posso antecipar, prever, controlar, e com o qual tenho que me haver no exercício de minha liberdade. É essa relação com o outro que Sartre pretende enfatizar:

[...] a liberdade do outro revela-se a mim através da inquietante indeterminação de ser que sou para ele. Assim, este ser não é meu possível, não está sempre em questão no cerne de minha liberdade: ao contrário, é o limite de minha liberdade, seu "reverso", nesse sentido em que nos referimos ao "reverso da moeda"; [...] a própria matéria de meu ser é a imprevisível liberdade de um outro. (SARTRE, 2007, p. 337; grifos nossos)

Vemos como a mesma expressão que aparece na noção de liberdade negativa, a saber, o outro como "limite de minha liberdade", ganha na teoria existencialista um sentido que não o de obstáculo. Aqui, o limite da liberdade não é pensado como alguém que se antepõe como um estorvo à realização das escolhas do indivíduo, mas antes, dada a condição de fundamento que a figura do outro adquire para a liberdade do sujeito, esse limite se define como a impossibilidade de domínio completo, por parte do sujeito livre, de sua ação e de suas consequências. Em outras palavras, colocar o outro como fundamento - e limite - da liberdade é afirmar a condição imprevisível, inantecipável do ato livre. O outro que me aparece não me remete "a experiências possíveis, mas a experiências que, por princípio, estão fora de minha experiência e pertencem a um sistema que me é inacessível." (SARTRE, 2007, p. 295).

Sartre é um autor que pensa o problema da liberdade colocando-se criticamente em relação às teorias individualizantes sobre o tema. Para o filósofo, o eu só é em presença do outro. A concepção de que "eu tenho meu fundamento fora de mim" afirma a relação com o outro como constitutiva da experiência de liberdade. "O outro é o mediador indispensável entre mim e mim mesmo" (SARTRE, 2007, p.290). A tensão constante que se presentifica na relação com o outro - uma relação que tem a marca da liberdade humana - se deve, para Sartre, ao fato de que os sujeitos estão a todo momento tentando apreender quem é o outro, ao mesmo tempo em que este que se quer apreender (pelo olhar, por meio de juízos) sempre escapa à objetificação. Do mesmo modo, o sujeito se percebe sendo apreendido pelo outro, e essa situação desconfortável (porque reduz o sujeito a uma imagem, à condição de objeto, destituindo-Ihe de sua subjetividade) é por ele recusada. O exercício da liberdade é constitutivamente conflituoso. Nos termos de Sartre, "O conflito é o sentido originário do ser-Para-outro." (SARTRE, 2007, p. 454).

Em O Ser e o Nada, Sartre prioriza a discussão da liberdade na relação intersubjetiva eu-outro. O outro é um desconhecido, por 
definição, isto é, não pode ser pensado à minha imagem e semelhança, antecipado ou controlado. Ainda assim - e por conta disso a angústia se faz presente - tenho que me haver com o outro no exercício da liberdade: "a própria matéria de meu ser é a imprevisível liberdade de um outro." (SARTRE, 2007, p. 337). Estando emaranhado no outro que não se pode prever, a existência do outro funda a impossibilidade de domínio completo do sujeito sobre suas ações livres e sobre suas consequências.

Entretanto, é na Crítica da Razão Dialética (em especial no segundo volume) que Sartre vai discutir o agir livre em sua dimensão coletiva, nos grupos humanos. A importância dessa obra para o campo da psicologia é enorme, uma vez que ela aborda a ação livre a partir do sujeito, mas considera a dimensão coletiva imprescindível para que esse processo seja compreendido. Quando dizemos "dimensão coletiva", cumpre destacar que esta não se compõe de indivíduos semelhantes: surge aí a figura do terceiro como instância não idêntica ao sujeito. É essa não-identidade que confere a imprevisibilidade aos fenômenos humanos. Para Sartre, o erro comum dos sociólogos (e de todos os estudiosos dos grupos humanos) é de considerarem "o grupo uma relação binária (indivíduo-comunidade), quando trata-se de uma relação ternária." (SARTRE, 2003, p. 473).

No segundo volume da Crítica, Sartre se dedica a discutir os processos de constituição dos agrupamentos humanos em diferentes momentos, procurando, através da crítica, determinar sua racionalidade. O filósofo se pergunta a partir de quais circunstâncias exteriores se constituem os grupos, e identifica que essas circunstâncias são bem distintas dependendo do tipo de grupo é formado, no que diz respeito à sua complexidade e sua coesão. Entretanto, é nas relações intersubjetivas que o grupo é ressignificado, totalizado ou mesmo fragmentado. Sartre reserva a essas relações a chave para a compreensão do agir livre em coletividade sem, com isso, descartar a dimensão subjetiva, como o fizeram tantos pensadores que analisaram a formação e 0 comportamento das massas e turbas, e mesmo das instituições e organizações. Ele afirma:

\footnotetext{
Essa dialética do grupo é, certamente, irredutível à dialética do trabalho individual, mas sua existência também não subsiste por si mesma. Assim, [...] sua inteligibilidade é a de uma Razão constituída, cuja dialética da livre práxis individual seria a Razão constituinte. (SARTRE, 2002, p. 506, grifos do autor)
}

Tomemos como um exemplo dessa dialética a situação de juramento num grupo. O filósofo qualifica o juramento como "invenção da permanência prática" num grupo em função dos constantes perigos 
de fragmentação que esse grupo pode sofrer. Esses perigos não são necessariamente de origem externa ao grupo, mas surgem justamente porque o grupo é formado por sujeitos livres:

[...] a possibilidade de uma livre secessão manifesta-se como possibilidade estrutural de cada práxis individual; e essa possibilidade revela-se em cada outro terceiro como a mesma enquanto esse terceiro, aqui, a redescobre em si. [...] Quando a liberdade faz-se práxis comum para servir de fundamento à permanência do grupo, produzindo por si mesma e na reciprocidade mediada sua própria inércia, esse novo estatuto chama-se juramento. (SARTRE, 2002, p. 514)

O juramento, como "reciprocidade mediada", é a implicação recíproca dos membros de um grupo nas promessas feitas. É a garantia que uns oferecem aos outros de que não vão mudar no futuro, que permanecerão leais ao juramento feito. É preciso entender $o$ juramento no grupo não como um obstáculo à liberdade individual, como o liberalismo o conceberia (tanto é que o juramento sartriano não pode ser lido como o contrato social hobbesiano), mas como realização, obra da própria liberdade. Ele funciona como "minha caução contra mim mesmo" e, ao mesmo tempo, regulação do terceiro no grupo. Ele é permanente exercício da liberdade porque a todo momento eu, ou outro integrante do grupo, pode decidir livremente abandonar o grupo, traí-lo, se aliar a um grupo de oposição ou inimigo. A esse respeito, Sartre destaca:

É evidente que "livremente" - aqui, como em toda parte
neste estudo - refere-se ao desenvolvimento dialético de
uma práxis individual, surgida da necessidade e que supera
as condições materiais em direção a um objetivo preciso.
Portanto, a traição e a deserção provocadas pelo terror ou
sofrimento são, desse ponto de vista, livres práxis enquanto
condutas organizadas que correspondem a ameaças
externas. (SARTRE, 2002, p. 517).

A compreensão sartriana no juramento no grupo como puro exercício da liberdade nos ajuda a entender de que forma o autor articula liberdade, subjetividade e coletividade em seu texto. Ainda que seja pensado como um ato subjetivo, o juramento (assim como tantos outros processos coletivos) só pode ser significado no grupo. $O$ próprio sujeito só se apropria de seu ato quando este lhe é remetido pelos outros, pelo terceiro. O juramento, num grupo, implica seus integrantes nas promessas feitas, mas pode ser rompido a qualquer momento. Trata-se de uma imagem bem esclarecedora a respeito da liberdade em Sartre, que, como tentamos explicitar aqui, distingue-se radicalmente da concepção individualizante e autossuficiente da liberdade no liberalismo. 
Além disso, o entendimento da dimensão de intersubjetividade que constitui o humano torna mais clara a abordagem de Sartre quando o autor valoriza o aspecto ativo da liberdade, do fazer, do inventar. Pensar um cenário em que as marcações de pertencimento, orientação e garantia são socialmente confusas e ambíguas, como é o caso da cidade contemporânea, e refletir sobre as relações aí estabelecidas, pode ganhar outros sentidos ao tomarmos a proposta existencialista de que os valores precisam ser inventados na ação livre. "O conteúdo [da decisão] é sempre concreto e, por conseguinte, imprevisível; há sempre invenção. A única coisa que importa é saber se a invenção que se faz se faz em nome da liberdade." (Sartre, 1987, p. 20).

Falar de decisões e de escolhas, de julgamentos e de valores na teoria existencialista é, sem sombra de dúvidas, falar de atos humanos que se dão em situação, isto é, em contextos reais, envolvendo pessoas existentes. Enfatizar esse aspecto é crucial para entendermos em que sentido o existencialismo se coloca crítico à liberdade negativa, ao conceito de livre arbítrio e à ideia de autonomia racional - todas essas, definições formais e vazias, que prescindem do contexto em que se realizam para serem definidas.

\section{A alienação como liberdade alienada : considerações sobre as formas de alienação do ser livre no mundo do trabalho}

Nosso objetivo neste item é pensar a alienação como liberdade alienada. Nossa primeira tarefa consiste em considerar brevemente a noção de liberdade, dentro dos limites da filosofia sartriana e mostrar como tal noção implica a alienação como seu correlato ontológico fundamental. Em seguida, trataremos as formas de alienação do ser livre no âmbito da racionalidade capitalista, com o objetivo de mostrar o crescimento progressivo do domínio do campo prático inerte sobre a práxis individual a ponto de assistirmos, nos dias de hoje, o ápice desse processo no problema do suicídio ligado as condições de trabalho (CASTRO, 2011).

\subsection{Liberdade e alienação}

A liberdade pode ser definida como a livre práxis, que nega e ultrapassa o campo sócio-material passado e presente em direção a um porvir (SARTRE, 1985). É assim que o próprio ato de projetar-se e temporalizar-se, inerente a práxis humana, aparece como livre, à medida que tal ato dá-se sempre como a realização de um possível dentro de um campo de possíveis. Um processo, portanto, de criação histórica, visto que toda liberdade reenvia a uma práxis constituinte da historicidade tanto singular como coletiva. 
No entanto, toda práxis constituinte não existe como pura subjetividade que se transcende em direção a seus fins, mas como "subjetividade objetivada" (SARTRE, 1985). Ou seja, como objetivação de si no mundo sócio material, como a marca de seus projetos fixada nos objetos e na práxis alheia. Escrever um artigo, dar uma palestra, ler um livro, discutir com alguém, tocar um instrumento, dar uma aula, são formas da subjetividade se fazer mundo, de ganhar uma forma impressa na vida dos outros e nas coisas, quer dizer, de totalizar-se organizando e significando o campo prático. A objetivação, neste sentido, é o próprio ser livre existindo para além de mim, nas coisas e nos outros, como forma essencial do processo de fazer-se.

Assim, a liberdade definida como livre práxis e como objetivação, aparece como condição de possibilidade da alienação. Quer dizer, como a condição de alteração mais ou menos profunda de minhas objetivações pela livre práxis dos outros dentro de um campo socialmaterial estruturado. A alienação, como correlato ontológico da liberdade, implica, portanto, que toda liberdade, ao mesmo tempo em que atravessa o campo social e fixa suas marcas na história dos outros e nos objetos, é também atravessada pelo campo social e pelas práxis alheias, estando assim, sujeita a distorções, modificações e inversões produtoras do estranhamento do sujeito em relação a si mesmo. A alienação, dessa forma, é o outro que me torno, não como simples resultado de minha livre práxis, mas como resultante das atividades dos outros que se apropriam de minhas objetivações e alteram seu sentido. Por essa razão, é possível definir a alienação como uma liberdade alienada, sem deixar por isso de ser liberdade.

Para aprofundar a questão, faremos um pequeno retrocesso a Hegel na sua dialética do senhor e do escravo (HEGEL, 2008 [1807]). Para Hegel, o escravo se faz escravo, na medida em que realiza pela luta com seu senhor, uma renúncia de si mesmo em prol da vontade soberana, e o senhor faz-se senhor, quando seus atos correspondem a uma renúncia da liberdade do escravo em prol de sua vontade que prevalece. Desta maneira, temos que o ser do escravo deixa de ter qualquer caráter substancial, para tornar-se uma realização histórica caracterizada pela renúncia de sua liberdade em função da vontade do outro, ou seja, um processo que implica a práxis escrava se despossuindo de si para ser governada pela vontade do senhor. 0 escravo, assim, realiza seu ser fora de si na liberdade do senhor. Mas o contrário também se mostra verdadeiro, visto que o senhor somente realiza-se como tal quando o escravo renuncia o ser para si fazendo-se para o outro conforme a liberdade do senhor. O que quer dizer que o ser do senhor realiza-se não somente em si mesmo na sua soberania, mas fora de si pela práxis de renúncia do escravo, bem como pelo seu trabalho. Um perpétuo "ser para além de si 
mesmo no outro" como sublinha Sartre (1985), dando à relação de dominação o caráter de uma luta recíproca.

Porém, como sustenta Sartre, "a falha de Hegel é não reconhecer que a materialidade é o intermediário necessário entre duas liberdades" (SARTRE, 1985, p.224). Ou seja, para aprofundar a dialética hegeliana que compreende a alienação como luta e conflito entre duas liberdades (KOJĖVE, 2002), faz-se necessário compreender as condições sócio-materiais que tornam possível a renúncia do escravo de sua própria liberdade em prol da vontade do senhor. Nesse sentido, o poder do senhor não se baseia na aceitação desse por parte do escravo, mas a "aceitação de seu poder é, na verdade, a interiorização da impotência em recusá-lo" (SARTRE, 1985 : p.714). Quer dizer que a situação sócio-material em que se encontra o escravo é de tal ordem, a ponto de lhe colocar na impotência diante da vontade soberana do senhor. A impotência, portanto, revela uma forma de organização coletiva do escravo constituída pela serialidade (SARTRE, 1985) como característica de um determinado conjunto humano que implica, por um lado, a solidão de cada um face aos demais (não posso contar com os outros, não confio em ninguém, tenho que fazer a minha parte, etc.,) e, por outro, relações de intercambialidade e de alteridade serial. Ou seja, vejo-me fazendo parte, como todos os outros, da mesma série (sou o mesmo que os demais e ocupo um lugar na ordem serial). No entanto, essa relação de reconhecimento mútuo está fundada na dependência comum a um campo prático inerte que organiza do exterior o coletivo serial: "A série é um modo de ser do individuo" como diz Sartre (1985), no qual a unidade dele com todos os outros e de todos os outros com ele é dada sempre alhures, dependendo de um ser fora de si que determina e organiza o tempo e a vida coletiva. O escravo, portanto, renuncia livremente seu ser livre pela impotência de afrontar o poder do senhor sozinho e vê-se constrangido por todos os outros a manter-se escravo em função de encontrar-se inserido em um coletivo serializado dentro do qual vive relações de isolamento e de mútuo condicionamento em função das exigências do campo prático inerte as quais estão todos submetidos.

\subsection{Formas de alienação do ser livre no mundo do trabalho}

A fim de pensar mais concretamente as formas de alienação do ser livre em meio a coletivos serializados, convém situar a especificidade social-histórica da instituição capitalista, que possui como um elemento decisivo "não a acumulação como tal, mas a transformação contínua do processo de produção visando o crescimento do produto combinado com a redução dos custos" (CASTORIADIS, 2004, p.98). O empreendimento capitalista busca, assim, justificar-se por seu "racionalismo econômico", baseado na maximização do produto 
conjugada à minimização dos custos, via uma utilização eficaz dos recursos. É à luz desse novo valor, instituído como racional e dominante, que nascem dois elementos fundamentais para 0 desenvolvimento da racionalidade capitalista: o homo oeconomicus como individualidade típica da era capitalista e o papel da técnica. O ser humano transforma-se em homo oeconomicus à medida em que existe no mundo tentando constantemente maximizar-minimizar suas utilizadades-desutilidades, seus custos-benefícios, sendo um homem que calcula e move-se pelo princípio da eficácia. Por outro lado, o papel da técnica pode ser visto também como outra transformação essencial dentro da nova instituição capitalista que começa a dominar os países da Europa e em suas extensões coloniais a partir do século XVIII. Conforme Castoriadis "um traço particular dessa evolução da técnica deve ser destacado: ela é, de maneira preponderante, orientada para a redução e depois para eliminação do papel do homem na produção" (CASTORIADIS, 2004 , p.101). A instituição do capitalismo comporta, portanto, o fetichismo da técnica, ao torná-la essencial e fazer o homem que trabalha inessencial.

A utilização da burocracia pela empresa capitalista como forma de organizar o trabalho é o primeiro grande esforço, no âmbito do mundo do trabalho, para eliminar o papel do humano dentro da estrutura produtiva. Após a Revolução Industrial na Inglaterra, a Revolução Francesa e o desenvolvimento econômico da Alemanha, a dominação de uma tecnocracia de engenheiros sobre a estruturação do campo prático industrial passou a imperar no âmbito do trabalho (POUGET, 1998), de forma a fazê-lo escapar ao controle de quem trabalha (TRAGTEMBERG, 2006). Pela primeira vez observa-se, em relação ao trabalho artesanal dos ateliês (POUGET, 1998), uma separação entre o trabalhador e os meios de produção: a divisão do trabalho passa a ser objeto de racionalização segundo os princípios do homo oeconomicus e o novo papel da técnica, transformando a organização em instituição (SARTRE,1985). Quer dizer: na fábrica pré-burocrática (ou seja, anterior à segunda Revolução Industrial) imperava o poder personalizado do burguês dentro de uma organização prática baseada no domínio do trabalhador sobre a técnica de trabalho. A fábrica burocratizada implica, ao contrário, que os cargos e as relações de subordinação sejam institucionalizados pelas normas e leis produzidas por uma tecnocracia: a organização do trabalho se hipostasia num sistema técnico de prescrição de cargos e de relações hierárquicas que impessoaliza a lógica organizacional e seu funcionamento. Obedecemos à racionalidade burocrática e não a fulano ou beltrano, realizamos trabalho conforme as prescrições do cargo e acatamos as ordens conforme a hierarquia e não por ser $X$ ou $Y$ que nos ordena. Conforme Sartre "a instituição, como renascimento da serialidade e da impotência, precisa consagrar 
- poder para garantir sua permanência pela lei. Sua autoridade repousa na inércia e na serialidade" (SARTRE, 1985, p.686).

A ordem burocrática dentro da fábrica é, portanto, a primeira grande invenção do homem burguês para dominar tecnicamente a organização do trabalho, obedecendo ao princípio racional de maximização da produção e minimização dos custos, promovendo uma utilização eficaz dos recursos. O ideal, portanto, do racionalismo burocrático dentro da empresa capitalista, seria que cada um se comportasse estritamente conforme o cargo prescrito e obedecesse incondicionalmente à ordem hierárquica, para, dessa forma, o sistema maximizar a produção e minimizar seus custos. Ou seja, o ideal é transformar o homem em inessencial diante da instituição burocrática fetichizada pela técnica. O objeto prático inerte produzido pelos tecnocratas da administração burocrática está justamente na instituição dos cargos, da ordem e dos procedimentos, capazes de organizar-subordinar o trabalho coletivo às normas-leis impessoais. A livre práxis descobre-se assim, organizada do exterior, separada de qualquer poder sobre os meios de produção, submetida ao racionalismo contábil do homo oeconomicus e ao fetichismo da técnica prescrita pela tecnocracia. A práxis constituinte está, portanto, desde a raiz, alterada em sua historicidade, visto que encontra-se alienada de si em prol da lógica fabril, que se apropria da objetivação da subjetividade em benefício da eficácia produtiva. Um sistema, dessa forma, serializante desde sua raiz, pois estrutura o campo prático de cada um do exterior, via a instituição de normas, cargos e da ordem, visando a supressão do singular em prol do universal, constituindo um sistema de relações em que o Eu é dirigido pelo Outro (TRAGTEMBERG, 2006). A práxis soberana torna-se, portanto, aquela da autoridade institucional do conselho executivo da empresa e de seus técnicos de produção, que se impõe por meio da instituição burocrática como a "razão imperante", ou seja, como organizadora racional do campo prático sob a forma de mediador único, essencial e não recíproco para cada trabalhador. Todos necessitam mediarem-se em sua atividade de trabalho unicamente pela instituição, como organizadora unívoca e essencial do trabalho comum. A livre práxis transforma-se assim, em práxis institucionalizada (SARTRE, 1985) do trabalhador serializado face à ação organizadora e não-recíproca da praxis soberana institucionalizada. Cada trabalhador, no âmbito na nova fábrica burocratizada, produz-se interiorizando o caráter essencial da racionalidade burocrática e o caráter inessencial de sua própria práxis, ou seja, realiza-se a si mesmo como ferramenta do projeto do Outro.

Assim, através dessa relação unívoca e inessencial, cada trabalhador institucionalizado desfaz-se de sua própria liberdade em proveito da eficiência inerte da burocracia, sendo o caráter serial do processo 
encontrado no fato de todos fazerem o mesmo e, portanto, passarem a se comportar serialmente. No entanto, tal forma de desfazer-se de si implica um trabalho sobre si, um trabalho da própria liberdade singular para recusar o que lhe é próprio em prol da liberdade do Outro que ela atualiza. A alienação aparece neste nível como "a vida do Outro que se realiza por intermédio de minha própria vida" (SARTRE, 1985, p.714), não por uma pura recusa de "arriscar a própria vida" como diria Hegel (KOJĖVE, 2002), mas como "obediência na serialidade", quer dizer, como obediência mediada pela práxis coletiva de meus vizinhos que também obedecem e, por isso, condicionam minha obediência como impotência.

O taylorismo e a Teoria Geral da Administração, que o primeiro ajudou a fundar, aparecem como uma importante renovação do burocratismo fabril e de seu poder serializante. A instituição burocrática, que separa a atividade de trabalhado (inessencial) dos meios de produção (essencial), ganha uma nova especialização técnica com a administração científica do trabalho, para a qual a ética da eficácia e a subordinação do homem à máquina tornam-se princípios essenciais (TRAGTEMBERG, 2006). A ética da eficácia traduz-se, em Taylor, pela análise minuciosa dos tempos e movimentos da atividade de trabalho e pela prescrição de cada tarefa, maximizando os tempos-movimentos em prol da produtividade ótima e do mínimo desperdício. A subordinação do homem à máquina e a tarefa prescrita aparece como imperativo da eficácia, visto que toda invenção de um novo gesto e toda liberdade de agir diante das exigências dadas seriam uma ameaça à racionalidade empresarial e, portanto, um erro inaceitável. A gestão de pessoal na fábrica taylorista ocupa, do mesmo modo, um lugar central. Baseia-se no recrutamento do homem certo para ocupar o lugar certo, na formação que visa melhor treinar para o exercício do desempenho da tarefa prescrita, num controle rigoroso baseado em uma vigilância rígida e, ainda, em uma política de salário que se pretende motivante\punitiva para que o trabalhador aceite submeterse à ética da eficácia. Desenha-se, desse modo, uma renovação essencial da organização burocrática, baseada na centralização do trabalho de concepção em um departamento especializado, no qual os engenheiros de produção programam a máquina industrial dentro dos princípios técnicos baseados na análise dos tempos-movimentos e na consequente prescrição das tarefas e da gestão eficaz dos recursos materiais e humanos.

Com o advento da fábrica taylorizada e com as posteriores inovações administrativas de Fayol, Elton Mayo e, por conseguinte, da consolidação da Teoria Geral da Administração, cria-se uma gestão empresarial especializada em produzir um campo prático inerte capaz de subordinar o trabalho coletivo às exigências de eficácia, produtoras da serialização. Conforme Tragtemberg, com o advento do 
taylorismo vê-se um processo "de valorização do capital pelo trabalho em que o operário não utiliza os meios de produção. São estes que o utilizam (...) e sua maior preocupação concentra-se no fluxo mecânico dos objetos e na manipulação humana conforme critérios utilitários" (TRAGTEMBERG, 2006, p.241). O coletivo serializado, concebido como máquina tecnicamente planejada para produzir o máximo com o mínimo de porosidade é, portanto, o ideal da fábrica cientificamente administrada. A grande inovação serializante, trazida assim pela administração cientifica do trabalho, encontra-se na "análise do trabalho", que possui como critério essencial a ética da eficácia. Em síntese, produziu-se uma inovação técnica (a análise do trabalho) como meio de criar um novo objeto prático inerte (a prescrição da tarefa cientificamente estabelecida) que passou a operar como organizador essencial e único de cada práxis individual. A fábrica, agora cientificamente organizada, implica, dessa maneira, no aumento do poder alienante da burocracia, visto que aparece como uma especialização do modo de utilização/alteração da livre práxis objetivada em função de um racionalismo produtivo renovado.

\subsection{A liberdade alienada dentro do mundo do trabalho contemporâneo}

Seria um enorme equívoco considerar os novos princípios gestionários, nascidos nos últimos trinta anos para administrar a empresa capitalista, como essencialmente diferentes das preocupações que motivaram tanto o surgimento do racionalismo burocrático quanto da administração taylorista (CASTRO, 2011). O new management, a teoria do capital humano, as novas regras de excelência (GAULEJAC, 2005) vieram a constituir as noções de base de um sistema gestionário formado a partir de uma situação de crise tanto da ideologia de justificação do capitalismo posta em cheque a partir dos movimentos de maio de 68, como também de sua reprodução, posta em cheque pela crise econômica do início da década de 1970 (BOLTANSKI \& CHIAPELLO, 1999). Um sistema que, seguindo rigorosamente os princípios do homo oeconomicus e do papel da técnica, inventa novas formas de produção serial dentro da empresa ao fazer crescer o poder organizador do campo prático inerte sobre a práxis individual.

Os movimentos de maio de 1968 possuíram tanto o caráter de revolta estudantil quanto o de revolta operária. Grosso modo, estudantes e trabalhadores enfatizaram a crítica à alienação, à miséria do cotidiano, à desumanização do mundo regido pela técnica, à falta de autonomia e de criatividade. No que diz respeito ao domínio do trabalho e da produção, a crítica recaiu sobre o poder hierarquizado, o autoritarismo, as tarefas prescritas, os horários e as cadências impostas, em suma, contra o sistema taylorista e a divisão 
do trabalho (CASAVECCHIE, 2008). A luta dos movimentos de maio de 68 , portanto, dirigiu-se contra os dois fundamentos de justificação do sistema social capitalista, quais sejam, contra a exploração (a chamada "crítica social") e contra seu caráter alienante (a chamada "crítica artística"), segundo Boltanski e Chiapello (1999). Em suma, maio de 68 foi um movimento social que se engajou na luta contra a exploração do trabalho e a favor da autonomia.

Por outro lado, os países industrializados, principalmente os da Europa ocidental e os Estados Unidos, passaram a viver uma grave crise econômica. O tripé keynesiano, formado pelo estado investidor e mediador, por uma política de bem estar social, e pela iniciativa privada, havia esgotado suas possibilidades de desenvolvimento e reprodução da ordem capitalista (HARVEY, 1992). A emergência das economias do leste asiático e a crise do petróleo exigiam a busca de novas formas de organização da produção que retomassem a produtividade e fossem capazes de enfrentar a nova competitividade internacional. E, por fim, o poder sindical, com sua capacidade de produzir um número elevado de movimentos de greve e frear a produção, representava, para a perspectiva do capital, um custo de produção a ser vencido.

Assim, o novo sistema de gestão que se desenvolveu como resposta a tais necessidades de justificação e de produtividade do capitalismo do final do século $X X$, constituiu-se de uma junção de dois aspectos antagônicos. Por um lado, ele assimila, à sua maneira, a crítica artística ao sistema, com suas reivindicações de autonomia e criatividade, que possui, por princípio, a reivindicação de humanização do trabalho e das formas de organização social. E, por outro, desenvolve novas formas de racionalização do trabalho, visando sua maior exploração a custos mais baixos. Aos novos técnicos da gestão empresarial coube, portanto, a responsabilidade de inventar uma nova forma de organizar e gerir o trabalho, portadora, desde sua raiz, de um paradoxo: propaga-se uma ideologia humanizante e justificadora das novas formas de organização e, ao mesmo tempo, produzem-se novas formas de exploração do trabalho para tornar os sujeitos hiperprodutivos.

Segundo Le Goff (1999), os preceitos de maio de 68 são integrados ao novo sistema ideológico manageriel, de maneira a desvinculá-lo de seu imaginário revolucionário original e a incorporá-lo a um discurso de modernização organizacional. O modelo não será o do trabalhador assalariado portador de um "saber-fazer", mas o do colaborador, comprometido subjetivamente com a empresa, e portador de um "saber-ser". A nova ideologia gestionária, portanto, desloca seu caráter prescritivo da atividade e de seus modos operacionais para o sujeito e seus modos de ser. Ser participativo, saber dialogar, aceitar críticas, ser tolerante, franco, engajado no progresso contínuo, aderido subjetivamente à empresa, passam a constituir princípios 
básicos da nova forma de gestão. Para Le Goff (1999), o "saber-ser" torna-se o coração do novo processo gestionário, com suas exigências de flexibilidade de tempo, competências, tarefas e deslocamentos, tudo isso, sobre a base de um discurso de desenvolvimento pessoal e individual. Conforme Gaulejac (2009), o ideal de excelência mostra-se um dos conceitos chaves das novas prescrições gerenciais, o que significa ser fora do comum e engajado subjetivamente em ser performante. A empresa, dentro dessa nova mentalidade gerencial, deixaria de ser um lugar de exploraçãoalienação para tornar-se portadora da modernização e do desenvolvimento individual.

Paralelamente a essa nova ideologia gestionária, uma nova racionalização do sistema produtivo se desenvolve. Uma síntese de suas principais características pode ser a seguinte. Uma busca pela "mensuração" rigorosa das competências, numa tentativa de quantificação cada vez maior da performance individual, qualificada por Le Goff (1999) e Gaulejac (2009) como uma espécie de quantofrenia. A "individualização" se ergue como um princípio, baseada nas medidas de salário variável em função da produtividade e nos dispositivos de avaliação individual (DEJOURS \& BËGUE, 2009). A "diminuição de custos" com salário torna-se sinônimo de modernização, seja a partir de demissões em massa (ANTUNES, 1999) ou da criação de diversas formas de subcontratação e de trabalho temporário, via terceirização e constituição de empresas de serviços, ajudando na transformação dos proletários em prestadores de serviço. Uma forte ofensiva contra o poder sindical faz parte ainda do novo sistema, na qual a contradição capital-trabalho e os temas tais como alienação e exploração tendem a ser banidos do interior da empresa em prol da exigência de colaboração e da ideia da organização como portadora de modernização. Uma gestão por objetivos, conforme sustentam Dejours e Bègue (2009) portadora de uma intensificação do ritmo das tarefas e de uma desqualificação do trabalho em prol de objetivos financeiros a curto prazo, torna-se fundamental. E, por fim, uma contradição entre manager, portador do novo modelo gestionário baseado na redução de custos, nas metas de produtividade e na ideologia do "saber-ser" e trabalhadores, portadores do "saber-fazer" próprios de sua atividade profissional. Gestão e trabalho, nesse sentido, distanciam-se um do outro, funcionando a partir de lógicas diferentes, motivo pelo qual, constata-se o aumento progressivo do assédio moral, da violência, da pressão e dos conflitos entre gestores e funcionários.

É possível compreender, a partir do exposto acima, que o paradoxo não constitui um acidente ou um desfuncionamento do novo sistema gerencial, mas é parte essencial de sua lógica serializante. Conforme Le Goff (1999), está-se diante de um management paradoxal, à medida que funciona a partir de duas lógicas antagônicas e, ao 
mesmo tempo, necessárias dentro da fábrica atual: é preciso ser autônomo e, ao mesmo tempo, ser em conformidade às normas estritas de produtividade e performance. 0 mesmo sustenta Linhart (2004), para quem o novo sistema manageriel desenvolvido para a modernização das empresas se estabelece a partir de duas demandas contraditórias: ser participativo e ser submisso. Da mesma forma, Gaulejac (2008) assinala que uma característica fundamental das mudanças vividas pelas empresas é a passagem da contradição ao paradoxo. Por um lado, a contradição de classe entre as categorias dos trabalhadores e dos patrões é substituída pela individualização radical e por uma lutte des places ${ }^{1}$, e a administração taylorista é substituída pelo novo management que, ao trabalhar para produzir o valor para os acionários, mostra-se incapaz de criar mecanismos de mediação sociais, levando ao crescimento da solidão serial. O paradoxo mostra-se, assim, o novo elemento serializante no interior da empresa capitalista, pois cria dois objetos práticos inertes que se opõem: de um lado, uma materialidade composta por exigências econômico-financeiras de hiperprodutividade com diminuição de custos e, de outro, um ideal de realização pessoal e excelência como forma do sujeito colocar sua própria existência - e não só sua força de trabalho - a serviço da maximização produtiva (GAULEJAC, 2009). O campo prático inerte constituído pela nova empresa é então, aquele do ideal irrealizável (DUJARIER, 2006). O homo oeconomicus, calculador, que avalia as ações de forma a otimizar a produtividade, a aproveitar ao máximos seus recursos e diminuir ao mínimo suas perdas, se desloca do bureau des méthodes para um ideal de personalidade ao qual todos exige-se que todos adiram. Conforme a nova teoria do capital humano (GAULEJAC, 2009), o indivíduo e suas capacidades cognitivas, afetivas e relacionais passa a ser concebido como um capital a fazer frutificar e a se fazer valorizar para melhor enfrentar a luta pelo emprego, dentro de um mercado cada vez mais competitivo. Por outro lado, o computador, i-phones, tabletes, bem como, as avaliações individuais, passam a compor o novo campo prático inerte dentro da empresa modernizada com suas exigências, ritmos, formas de pressão e objetivos fixados do exterior que inviabilizam qualquer ideal de realização pessoal. O poder serializante das novas formas de gestão evidencia-se, portanto, pela unidade formada por dois objetos prático inertes contraditórios: o ideal de saber-ser e excelência individual e uma realidade prática de super exigência produtiva. A libre práxis objetiva-se, dessa maneira, em um campo prático extremamente alienante. O trabalho realizado (enquanto subjetividade objetivada) nunca é suficiente, pois é profundamente alterado pela exigência de ter que ser fora do comum. E, como complemento, as objetivações do trabalho do sujeito para os outros são utilizadas contra o próprio sujeito, como 
um meio na luta competitiva pelo ideal de excelência buscado por cada um contra todos os outros.

O que há de comum entre o racionalismo burocrático, a administração científica do trabalho e a nova ordem manageriel é, sem dúvida, a estruturação de um campo prático inerte dominante, que visa despossuir o homem de si mesmo e fazê-lo aceitar a estruturação de seu ser fora de si, tal como realizada pelo Outro. Ou seja, a empresa capitalista, perseguindo o projeto fundamental e fundante de sua racionalidade econômica, possui na serialidade $o$ fundamento da organização do coletivo. Tal condição coloca a livre práxis individual e constituinte de historicidade sob tensão, visto que a cada um cabe a necessidade de renunciar a si mesmo para existir conforme a ordem instituída, fazendo com que a ação individual torne-se a interiorização da vontade do Outro. Existir como cargo na empresa burocrática, como coisa/recurso dentro organização taylorista, ou como recurso-excelente dentro da nova ordem manageriel implica, nesse sentido, em uma dupla tarefa que unifica liberdade e alienação no âmbito de cada práxis individual. Por um lado, a necessidade assumida e vivida de agir sobre si mesmo tendo que renunciar o desejo de ser e de fazer singular, que se evidencia um duro e violento trabalho de mutilação de si mesmo. Segue-se a segunda tarefa, complementar à primeira, de fazer-se conforme os fins estranhos a si, ditados pelo campo prático inerte organizado do exterior pelos experts na organização do trabalho. A livre práxis individual faz-se, assim, como interiorização da vontade do Outro que se impõe como reguladora de um coletivo serializado em prol de um objetivo organizacional de produtividade máxima e mínimo desperdício.

\subsection{Esboço da inteligibilidade da ação de classe e do crescimento da alienação em nossos dias}

A nosso ver, a especificidade da alienação produzida pelas novas formas de gestão do trabalho aos nossos dias, encontra-se no seu caráter individualizante e, por consequência, destrutor das formas de ser em comum (CASTRO, 2010). Baseando-nos na Critique de la Raison Dialectique de Sartre (1985), especialmente quando o filósofo trata de nos fornecer uma inteligibilidade dialética da ação de classe, quer dizer, que não perca de vista a livre práxis individual e de grupo negando o dado e totalizando o campo sócio-material para fazer a história, é possível considerar que vivemos, atualmente, um crescimento do domínio do campo prático inerte e da serialidade.

A inteligibilidade da ação de classe trazida por Sartre na Critique implica, segundo Simont (1998), três aspectos fundamentais: a existência de grupos como pura combatividade, que ao romperem a impotência serial operam a fusão da práxis individual em uma práxis 
comum e organizada, capaz de negar a ordem instituída em prol de um futuro outro. Junto com a existência dos grupos combativos, encontraríamos ainda, de um lado, a classe enquanto dispersão serial e, de outro, os aparelhos institucionalizados tais como partidos, sindicatos, etc. Portanto, a ação de uma classe sobre a outra, como por exemplo, a capacidade de impor licenciamentos de massa por parte da grandes empresas com objetivo de aumentar o valor das ações para os acionários (CASTRO, 2011), os ajustes econômicos que visam a acomodação fiscal para que os Estados possam honrar seus credores internacionais, dependem, para serem bem sucedidos, da configuração interna de uma determinada classe em relação à outra. A instauração do taylorismo na França somente teve êxito depois da segunda guerra mundial, visto que no entre guerras os grupos de trabalhadores como pura combatividade predominavam face à impotência serial e sua dispersão passiva. É possível assim, segundo Clot (2010), compreender o processo de instauração da administração científica do trabalho na França como estando em função, por um lado, do crescimento da oferta de mão de obra desqualificada oriunda das colônias, bem como, por outro lado, por um crescimento da burocratização dos grupos combativos, via o fortalecimento dos partidos comunistas e sindicatos. Ou seja, a dialética da classe trabalhadora francesa transforma-se, no pósguerra, no sentido de uma institucionalização-burocratização de suas estruturas e de um aumento da impotência serial, o que, por sua vez, tornou a luta pela implementação da organização cientifica do trabalho nesse país possível de ser realizada por parte da classe dos proprietários das grandes indústrias.

Se tomarmos ainda como exemplo o movimento dos trabalhadores paulistas do $A B C D$ no final dos anos setenta do século $X X$, é possível também considerar a ação de classe sob o mesmo prisma: a constituição de grupos enquanto pura combatividade, que foram capazes de fundar as câmaras setoriais no interior das empresas, constituídas por trabalhadores e empresários e feitas para discutir a política para o setor metalúrgico, uma expressão da predominância dos grupos organizados sobre a dispersão serial no interior da ação dos metalúrgicos naquele contexto.

No entanto, é possível observar, nos dias atuais, uma transformação profunda na ação de classe. A crise do ideal revolucionário essencialmente moderno, conforme Castoriadis (1992) - com o advento da chamada pós-modernidade, o crescimento da burocratização das estruturas sindicais e partidárias e, ainda, a consequente ampliação do coletivo serial, transformam profundamente as condições da ação no interior da classe trabalhadora. Por outro lado, a emergência de uma nova configuração da classe burguesa globalizada, constituída por uma "hiperburguesia" segundo expressão de Gaulejac (2009), composta por grandes 
acionistas, gestionários dos fundos de ações, banqueiros, conselheiros estratégicos e corretores de grandes agências financeiras, começaram a dar 0 ritmo às trocas financeiras. A economia passa a ser dominada segundo os princípios de instabilidade, da hiperatividade e de adesão ao presente, que impõem um nova organização do campo prático inerte, baseado no individualismo exacerbado e competitivo e na desconstrução dos laços sociais. Assistimos, desta maneira, um crescimento de um campo prático inerte imposto pela práxis dessa nova burguesia financeira globalizada, campo esse baseado na exigência de excelência (geradora de frustração) na escassez de tempo (geradora de hiperatividade) e de espaço (geradora de exclusão social).

A dialética hegeliana do senhor-escravo, enriquecida pela mediação das condições sócio-materiais de nosso dias, produtoras de um aumento da serialidade coletiva e da centralização do poder nas mãos de uma hiperburguesia financeira permite, portanto, considerar nossa época como permeada pelo crescimento da impotência e da insignificância (CASTORIADIS, 2002), quer dizer, por um aumento significativo da serialidade coletiva.

Um caso pode nos servir de exemplo para compreendermos a liberdade alienada dentro desse processo histórico de crescimento da impotência e da insignificância serial. Jean-Marc era conselheiro de patrimônio de um banco regional, que, ao final da década de 1990, foi incorporado ao banco Crédit Mutuel ${ }^{2}$. Filho de agricultor, através de seus estudos conseguiu chegar a ser bancário em 1980 e ascender na carreira para tornar-se conselheiro de patrimônio. Tinha orgulho de sua ascensão social e de seu trabalho, que consistia em orientar as pessoas em suas demandas, ajudá-las em seus interesses, numa relação de proximidade e confiança. Fazia seu trabalho o melhor que podia, com reconhecimento dos seus pares e junto com uma unida equipe formada por três colegas conselheiros de gestão. Para JeanMarc, ele havia encontrado sua identidade (MOREIRA \& PROLONGEAU, 2009).

Após a fusão entre seu banco e o banco Crédit Mutuel começaram uma série de transformações organizacionais. Ele começou a perder o domínio do seu tempo, porque o agendamento de seus compromissos passaram a ser feitos automaticamente por uma central, via internet. Não tinha mais autonomia de decidir o tempo que poderia ficar com um cliente, pois o tempo entre um cliente e outro era decido automaticamente em função das exigências comerciais de produtividade. Novos objetos prático inertes passam assim a existir, capazes de governar do exterior o tempo e o ritmo de seu trabalho. 0 objetivo do trabalho também se alterou: não era mais o "aconselhamento", segundo Jean Marc, mas sim o vender produtos e atingir as cifras estipuladas, fazendo com que o conteúdo de sua atividade mudasse radicalmente. Nota-se, neste aspecto, uma 
modificação do campo prático capaz de alterar profundamente $o$ sentido desejado de seu trabalho. Acrescentam-se, um método de gestão anônimo no qual as decisões chegavam por correio eletrônico, um sistema de individualização dos rendimentos que criava a concorrência com seus colegas e uma relação com seu manager direto baseada na cobrança diária de resultados financeiros e, tudo isso transpassado pela exigência de comprometimento com a modernização da empresa. Podemos observar, assim, o sistema de gestão paradoxal sendo posto em prática. Por um lado, a gestão do tempo e da performance individual feito tanto à distância (pelo computador) como de perto (pela pressão do novo gerente), capazes de tirar totalmente o poder de agir do sujeito sobre seu trabalho e alterar profundamente o seu sentido. Por outro, um sistema de injunções baseados num ideal de comprometimento que afirma a excelência pessoal/organizacional.

Mas Jean-Marc, por sua vez, queria atingir os objetivos fixados e não admitia fraquejar, porém, recusava a maneira como era exigido a fazê-lo. Eis, portanto, uma situação paradoxal vivida do interior. Ao mesmo tempo uma nova ordem produtiva que elimina o sentido do trabalho, cria a hiperatividade e corta os laços sociais, solicita, paradoxalmente, o engajamento subjetivo com os novos ideais de modernização organizacional. Jean-Marc participa desse processo não somente como objeto de manipulação, mas como livre práxis implicado em corresponder às injunções paradoxais, passando a fazer coisas que se tornam mais e mais insuportáveis para si mesmo. Observamos, nesse sentido, a liberdade alienando-se pelo processo de invalidação de si, aceitando a violenta alteração de sua objetivação em função da impotência serial: "Eu me sentia desprezível, pois eu cruzava com as pessoas [clientes] na rua no dia seguinte, e nunca, nunca eu quis que uma só dessas pessoas dissesse que eu era um ladrão, que eu havia abusado da confiança delas [...] eu me sentia rumo ao abismo [...] eu não conseguia mais me sentar no meu escritório! Quando eu chagava, eu já me sentia mal fisicamente, eu me disse um dia que eu poderia ficar violento, jogar o computador pela janela. Eu não queria chegar a esse ponto" (MOREIRA \& PROLONGEAU, 2009, p.42). Dessa maneira, quanto mais o sujeito responde às injunções paradoxais de engajamento subjetivo e hiperprodutividade, mais torna-se despossuído de si mesmo e mais transforma-se em um ser outro insuportável. Jean-Marc era quem mentia ou iludia seus clientes, e não mais quem os orientava, era quem competia com seus colegas e não mais quem estava ligado a eles e, ainda, era alguém que tinha se tornado desprezível para si e para os outros e não mais um orgulho e um modelo. Uma divisão entre seu ser para si desejável e seu ser para o outro instrumentalizado e totalizado desde o exterior pelas exigências do novo campo prático inerte. Jean-Marc, procura seu superior para 
dizer que os novos objetivos eram irrealizáveis mas recebe como resposta um reforço da pressão em cumprir suas metas. Ele buscou ainda resolver o problema junto ao diretor da agência, e tentou acesso à mais alta hierarquia, mas, devido ao anonimato da nova organização virtual do trabalho, não encontrou apoio nem suporte. Acrescentando-se a isso, foi fechando-se e isolando-se dentro de sua família, na tentativa de resolver por conta própria seus problemas no trabalho, um comportamento típico do homem serializado pelo ideal de excelência, que assume a inteira responsabilidade pelos seus fracassos. Uma reunião com seu diretor servirá de desencadeador de uma crise suicida. Exigido a escrever em um mural o número de contratos fechados durante a jornada de trabalho e informado que não teria mais secretária e que contaria, dali para frente, somente com seu computador, Jean-Marc entrou em crise. "Eu me sentia desorientado, sem ter como escapar [...] eu me perguntava onde é que eu estava, o que eu tinha feito da minha vida!". Fechou-se em seu escritório e viveu uma crise de choro. A noite não conseguiu dormir, ficando de pé a caminhar em círculos e olhando-se no espelho, até que pela primeira vez, pensou em suicidar-se.

Jean-Marc expressa a dialética senhor-escravo típica da nossa época, com sua forma específica de alienação do ser livre. Submetido às novas exigências paradoxais do novo sistema gestionário, vê-se cada vez mais diante da necessidade de operar sobre si mesmo a renúncia de seu modo de ser, precisando trabalhar e corresponder às demandas da nova ordem produtiva. A cada momento em que precisa agir sobre si mesmo, acumula-se a experiência de despossuirse e de realizar outro ser que aquele correspondente a seu projetodesejável. A impotência de Jean-Marc evidencia, ainda, a serialidade do coletivo produzida pelos novos agentes da reorganização empresarial. "É necessário, afirma Charles C., expert e conselheiro de empresas multinacionais cotadas na Bolsa, sentir-se em perigo, adaptar-se, investir. [...] eu trabalho para a desumanização da organização e do management, no sentido de suprimir tudo que é interno ao homem" (PIVERT, 2009). Charles C. e Jean Marc constituem, assim, a dialética alienante da liberdade de nossa época, caracterizada pela violência de uma libre praxis soberana sobre um coletivo cada vez mais serializado por uma situação paradoxal.

Somente a alienação, compreendida como liberdade alienada resultante do poder serializante da nova ordem produtiva, permite, a nosso ver, inteligir o sofrimento de Jean-Marc, sua crise e a formulação da ideação suicida. A alteração profunda do sentido de sua práxis, o trabalho sobre si mesmo que renuncia seu modo de ser e fazer para adaptar-se a fins estranhos aos desejados, a impotência da situação serial fruto de uma situação de classe onde reina a apatia e a impotência, a reorganização do campo prático inerte orientado para a anulação do homem singular em prol da razão produtiva feito 
por uma hiperburguesia financeira globalizada, todos esse elementos são compreensíveis se consideramos liberdade e alienação como unidades de um mesmo processo. Uma liberdade como práxis constituinte e objetivação de si mesmo no mundo sócio-material onde necessita cada vez mais anular-se. Uma liberdade impotente e serializada que vê sua objetivação alterada e transformada pela nova ordem instituída, a ponto de não suportar mais caminhar pela rua e ficar face a face com as outras pessoas. Como diz Sartre, "quando obedeço a uma ordem, minha liberdade se destrói livremente, despojando-se de sua transparência para realizar aqui, nos meus músculos, em meu corpo em ação, a liberdade do outro. É a liberdade do outro, seja alhures, no outro, ou vivida por mim, que obtém sentido pela minha ação" (SARTRE, 1985, p.726).

\section{Eu e os "meus arredores": imaginário, criação, Literatura}

Itabira é apenas uma fotografia na parede. Mas como dói! Carlos Drummond de Andrade

A frase da epígrafe, do nosso poeta Carlos Drummond de Andrade, define nessas poucas palavras a essência da discussão deste item. Itabira, em Minas Gerais, é a cidade natal de Drummond, a partir da qual a noção de "pertencimento" pode ser claramente aplicada. A fotografia de Itabira na parede, que provavelmente ele olhava quando escreveu esta frase, era uma cidade tão viva quanto aquela pela qual caminhava na sua infância e juventude. Sua frase expressa, em outras palavras, que uma imagem não é apenas uma imagem, é muito mais que isso, mas é, ao mesmo tempo, também uma imagem. Isto também significa que a imagem possui uma conexão com o mundo, que é feita no "entre", na relação.

Para discorrer sobre a relação que as palavras do subtítulo deste texto anunciam - imaginário, criação, existencialismo, Literatura -, terei como horizonte de reflexão a noção "mes entours", meus arredores, que Sartre utilizou no seu livro O Ser o Nada (SARTRE, 2007, p. 619 e sgts). Tomei esta decisão para o percurso deste item porque percebo-a como fundamento para pensar a relação entre criação e imaginário, tão cara a todos nós, "artesãos intelectuais" ${ }^{3}$. De início, tratarei de alguns aspectos essenciais do imaginário e da criação, para então relacionar com "meus arredores". Existencialismo e Literatura estão sendo norteados à medida que o texto avança.

A noção de criação desperta sempre certa desconfiança entre alguns de nós, já que ela facilmente se liga a de imaginário, tão desqualificado pelas características que o encerram, como já apontei em antigo texto (EWALD, 1996). ${ }^{4}$ A referência ao imaginário é quase sempre tomada como algo "fora da realidade", "irreal", alguma coisa 
tão afastada da realidade que se torna "fantástica". É a partir dessa visada que muitos de nós usamos o termo imaginário para nos referirmos às artes de maneira geral. À exceção do movimento Realista-Naturalista na literatura e nas artes plásticas, cuja proposta era a representação não idealizada da realidade, a arte de representar, ou re-apresentar, supõe em si o direito a criar, inventar, idealizar, imaginar. Emile Zola (1840-1902), um ferrenho defensor do Realismo, que mais tarde reavaliou sua postura um tanto cientificista, afirmava em seu manifesto, O romance experimental (1982), que o artista escritor deveria submeter-se à fisiologia, isto é, expor especialmente as condições fisiológicas, a influência dos meios e das circunstâncias que determinam o que a pessoa é. Na sua visão, em pleno século XIX e no contexto de um cientificismo exacerbado, 0 romance, segundo ele, se reduziria à tarefa de experimentar e verificar as leis obtidas através da observação, segundo o modelo do método experimental do médico Claude Bernard. Foi o que realizou em vários de seus romances que nos servem, sem dúvida, de fonte documental sobre a sociedade e os estilos de vida no século XIX. O seu livro Como se casa, como se morre (ZOLA, 1999) é um dos melhores exemplos desta forma narrativa, apesar do seu tamanho reduzido. Talvez seja exatamente grandioso por isto: concentrar em tão pequeno espaço comportamentos evidentes das classes sociais sobre o casar e o morrer. Imbuído, portanto, das prerrogativas do positivismo sociológico e psicológico, ele afirma que

\footnotetext{
O Naturalismo, nas letras, é $[\ldots]$ o retorno à natureza e ao homem, a observação direta, a anatomia exata, a aceitação e a pintura do que existe. A tarefa foi a mesma tanto para o escritor como para o cientista (Zola, 1982, p.92).

[O romance naturalista] É impessoal, quero dizer que o romancista não é mais que um escrivão que se abstém de julgar e de concluir. O papel estrito de um cientista é expor os fatos, ir até o fim da análise, sem arriscar-se na síntese; os fatos são estes, a experiência tentada em tais condições dá tais resultados (ZOLA, 1982, p. 103-4).
}

Felizmente não estamos mais no século $X I X$ e o século $X X$ começa a ficar no passado. Felizmente as ideias de Emile Zola não vingaram ele mesmo foi um dos que reconheceu que foi sectário ao tentar transpor para o domínio das letras o método rígido do cientista (MANZANO, 2008, p. 142), acreditando piamente na ideia de que a ciência é neutra - e pudemos usufruir dos delírios artísticos de muitos escritores.

O problema sobre o qual tratarei neste item começa então a se delinear: ficção e realidade, imaginário e real. Dualidades inseparáveis, instigantes e fetichizantes, no sentido etimológico do 
termo fetiche: feitiço. É neste novelo cheio de nós que a criação se situa, representando, à sua própria maneira, a realidade; confrontando-a, ultrapassando-a, e nos incitando a refletir sobre nosso tempo, nosso futuro, nosso passado, sobre isto que chamamos "vida".

O problema então que se delineia é o da dicotomia real-imaginário. Em psicologia, na maior parte das vezes, tendemos a nos aproximar daquela ideia básica proveniente de uma visão da ciência baseada nas noções de certeza e precisão (EWALD, 2011). No domínio do ocidente e da ciência, com o primado da razão, optou-se, em certa medida, por abrir mão da riqueza proporcionada pelas formas de conhecimento, entre elas a do imaginário. Porém, em pleno século XXI, sabemos que a certeza e a precisão, que caminham paralelamente aos nossos fazeres e saberes, estão distantes dos anseios, pelos menos de alguns de nós, de construirmos uma psicologia nestes moldes. Então, resta-me aqui lidar exatamente com este "constrangimento", o da imprecisão, e esperar que vocês compreendam algumas das ideias que gostaria de compartilhar sobre esta questão que tanto me fascina.

Comecemos com algumas das noções que Jean-Paul Sartre expõe em A Imaginação, um texto dos anos 1930.

\begin{abstract}
A imagem de meu amigo Pedro não é uma vaga fosforescência, um rastro deixado em minha consciência pela percepção de Pedro: é uma forma de consciência organizada que se relaciona, à sua maneira, a meu amigo Pedro. É uma das maneiras possíveis de visitar o ser real Pedro. (SARTRE, 1980 , p. 110).

Não há, não poderia haver imagens na consciência. Mas a imagem é um certo tipo de consciência. A imagem é um ato e não uma coisa. A imagem é consciência de alguma coisa. (SARTRE, 1980, p.120, grifos do autor).
\end{abstract}

Para compreender o que ele está dizendo dentro do contexto destes seus dois trabalhos, gostaria de mostrar-lhes algo: 
JACK

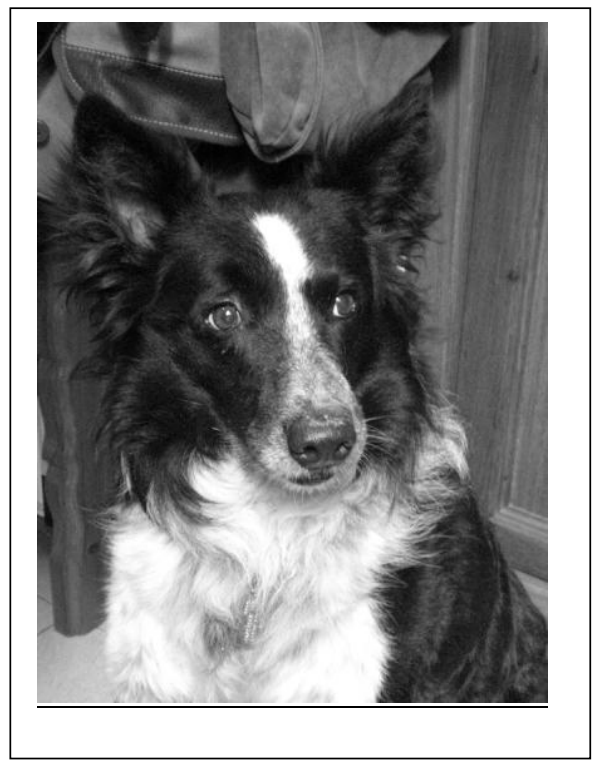

KIRA

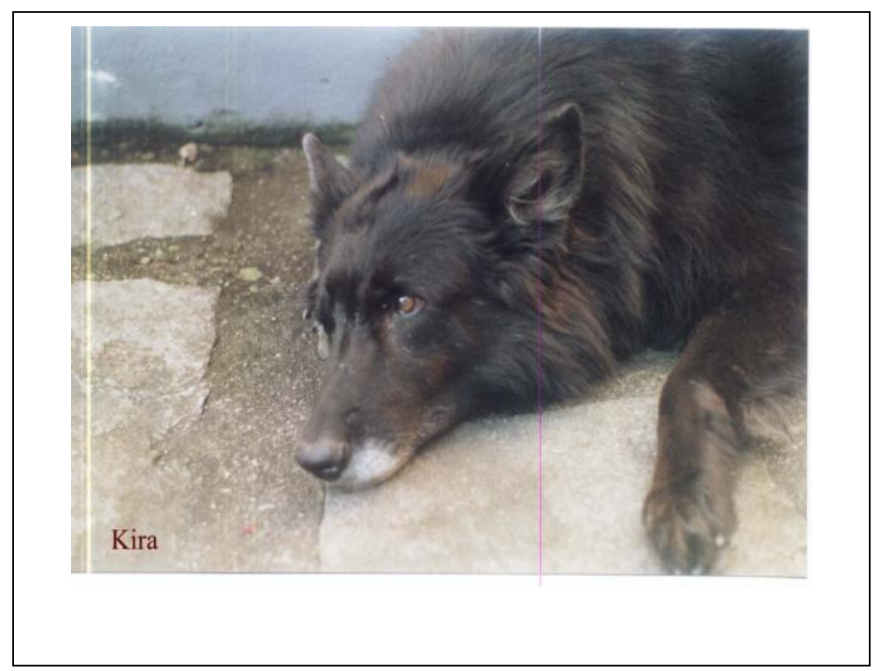

O que vocês veem são imagens - fotografias - de dois cachorros; eles moram comigo. O primeiro é o Jack, um border-collie de 9 anos, e o segundo é a Kira, uma pastor-belga de 13 anos. O que vemos, ali projetado, são manchas sobre um suporte organizadas de tal forma que consigo, claramente, distinguir Jack e Kira. Mas não é só isso. Sei que são imagens, que possuem características próprias, que são diferentes daquelas dos meus cães reais. Mas o fato de estarem ali, projetados, não significa que eles desapareceram; meus cães reais cessaram de ser para mim e, no entanto, ei-los ali diante de mim novamente.

Ora, se retirarmos as imagens projetadas, podemos facilmente trazêlos de volta: imaginem os meus cães; imaginem eles aqui neste auditório; eu imagino Jack correndo por entre as cadeiras atrás da sua bolinha - ele desce e sobe continuamente estas escadas e fica esperando que um de nós a jogue novamente para ele; e vejo também Kira, calmamente deitada ao meu lado enquanto estou lendo, olhando para mim atentamente - de vez em quando ela levanta a cabeça e me olha e volta a deitar. Estes cães que imaginei, assim como os que vocês imaginaram, são realmente Jack e Kira? Sim e não, diria Sartre, pois possuem qualidades bastante semelhantes com meus cães, mas não são Jack e Kira. A imagem que vocês criaram e a que eu criei, a partir das fotografias projetadas, tem uma "identidade de essência" com meus cães, mas essa "identidade de essência" dos meus cães não está acompanhada de uma "identidade de existência". São os mesmos dois cães, é verdade, mas eles aqui existem de outro modo, existem em imagem e são tão verdadeiros quanto os outros. São cães em "planos de existência" 
diferentes. Portanto, a imagem não é uma coisa, mas ela se constitui para mim enquanto objeto, na relação que eu estabeleço com ela. Isso significa que ao imaginar Jack e Kira, as imagens dependem de uma relação que estabeleço com este objeto a partir do meu imaginário, mas não significa dizer que as imagens de meus cães são os meus cães, nem que estas imagens são inferiores por serem "simulacros" de Jack e Kira. O fato de Jack e Kira não estarem aqui também não faz com que deixem de existir; as imagens são suas "aparições" e "se dão no momento mesmo em que aparecem como algo diverso de uma presença" (SARTRE, 1980, p. 6).

Ora, o que me parece claro aqui, é que falamos de uma identidade do "senso íntimo". Isto quer dizer que ao criar imagens para mim, estabeleço um vínculo com minha criação, uma relação de intimidade, de proximidade, de afetividade; estabeleço um tipo de senso íntimo. Estas imagens são e não são, portanto, parte de meu mundo; não são, já que são ausência; e são já que o que criei foi feito a partir da intimidade que estabeleço com estas ausências. Neste sentido, o sentimento que a imagem de Kira e Jack produzem em mim é o mesmo produzido por Kira e Jack "em pessoa". O que costumamos fazer corriqueiramente é confundir os dois sentimentos provenientes de objetos diferentes.

Ao colocar a fotografia de meus cães na minha carteira, por exemplo, nada mais faço do que buscar renovar/manter, constantemente, o mesmo sentimento que tenho por eles. Talvez coloquemos fotografias nas carteiras, celulares, ou as postemos no facebook, orkut e outras ferramentas tecnológicas, por acharmos bonitinho ou porque "todo mundo faz". Estes são "menores" como dizia Kant ${ }^{5}$, não possuem autonomia da razão e necessitam que outros lhes digam o que devem fazer. Mas muitos de nós colocamos estas imagens para renovar/manter o sentimento/afeto que temos por aquilo que ali se encontra retratado. A questão residirá sempre em não confundirmos os planos de existência e sabermos que uma imagem não restituirá a pessoa amada. O sentimento que tenho pela minha cachorra Kira continua sendo renovado cada vez que olho sua imagem. Apesar de ela ter morrido há sete anos e suas lembranças estarem um pouco esmaecidas, a cada visada minha ela se reconstitui, se renova e tento manter íntegros meus sentimentos por ela. Jack é outra história, ele agora está com nove anos.

O que Sartre chama de "metafísica ingênua da imagem", é esta não discriminação entre os planos de existência e acreditar que a imagem, por ser semelhante ao objeto, existe como o objeto, isto é, existe como coisa.

Em certa medida, podemos dizer que este "senso íntimo" que criamos com as imagens, pode ser pensado também como uma reconstituição da experiência. Esta é, para mim, a conexão para a literatura como constituição da experiência. É isto que propõe Simone de Beauvoir 
em seu texto, pouco lido e comentado: Literatura e Metafísica, de 1946. "É no seio do mundo que pensamos" (1965, p.80), afirma ela, ao indicar que muitos de nós ficamos perturbados quando percebemos a separação entre um mundo gestado através de um romance e um outro, gestado pelos tratados filosóficos.

\begin{abstract}
Se alguns escritores escolheram reter apenas um destes dois aspectos da nossa condição, erguendo assim barreiras entre a literatura e a filosofia, outros, pelo contrário, procuraram desde há muito exprimi-lo na sua totalidade. O esforço de conciliação a que hoje se assiste situa-se na sequência de uma longa tradição, responde a uma exigência profunda do espírito. Porque suscita, então, tanta desconfiança? (BEAUVOIR, 1965, p. 80).
\end{abstract}

Ainda temos encontrado esta desconfiança. A ficção ainda é vista com um olhar atravessado e despossuída de sentido de verdade. Mas sua proposta nunca foi esta, nem se pode pensar que a ficção está disposta a se contrapor à linguagem da ciência na busca de uma verdade absoluta. Nem a ciência faz isso. Quem o faz são aqueles que se consideram absolutamente sapientes do que significa ciência e nesta sapiência, depositam sua limitação, sua miopia, como já disse Drummond neste poema.

\title{
A Verdade Dividida
}

Carlos Drummond de Andrade

A porta da verdade estava aberta
Mas só deixava passar
Meia pessoa de cada vez.
Assim não era possível atingir toda a verdade
Porque a meia pessoa que entrava
Só trazia o perfil de meia verdade
E a sua segunda metade
Voltava igualmente com meios perfis
E os meios perfis não coincidiam...
Arrebentaram a porta.
Derrubaram a porta
Chegaram ao lugar luminoso
Onde a verdade esplendia seus fogos
Era dividida em metades
Diferentes uma da outra.
Chegou-se a discutir qual a metade mais bela
E carecia optar.
Cada um optou conforme
seu capricho,
sua ilusão,
sua miopia.

Não é "por cuidado com ornamentação ou embelezamento", lembra Jacques Colette em seu pequeno livro Existencialismo, que muitos 
dos grandes pensadores como Kant, Hegel ou Schopenhauer, invocam poetas em seus textos. Também não é por acidente que se cita ou se faz remissão a romancistas, dramaturgos, pintores e poetas, pois suas palavras valem tanto quanto a dos filósofos e cientistas; e suas reflexões expressas em linguagem artística são, da mesma forma, tão profundas e importantes quanto as outras. Como afirma ainda Jacques Colette,

[...] Lidando sempre com o vivido, a prosa literária dá espontaneamente às palavras uma espessura, um peso de sentido que, aos olhos do filósofo, se mostra inicialmente inarticulável. [...] Não sendo ciência rigorosa, a filosofia contém "uma prosa literária escondida", conserva um mínimo de equivocidade graças à qual se pode salvaguardar alguma coisa do vivido $[\ldots]$. (2009, p.115)

Já citei em outros textos vários autores/pensadores que reiteram esta concepção e não quero aqui me repetir. Esta discussão está também evidente no livro que organizei - Subjetividade e Literatura (EWALD, 2011) - cujos autores dos 16 textos expõem, cada um à sua maneira, esta relação tão próxima que nós, psicólogos, deveríamos ter com a Literatura. Ao mesmo tempo, gostaria de chamar atenção para o trabalho de James Wood, ensaísta, romancista e crítico literário inglês, Como funciona a ficção, publicado em 2011 no Brasil. O argumento forte e amplo neste seu livro, diz que "[...] a literatura é, ao mesmo tempo, artifício e verossimilhança, e que não há nenhuma dificuldade em unir esses dois aspectos" (2011, p. 12). Isto se dá por um motivo bem simples, mas que tendemos a ignorar: o uso da probabilidade. Para isto, ele lança mão do argumento de Aristóteles na sua Poética, na qual diz que

[...] a história nos mostra 'o que Alcebíades fez'; a poesia isto é, a narrativa de ficção - nos mostra 'o tipo de coisa que podia acontecer' a Alcebíades. Aqui, a ideia importante e subestimada é a plausibilidade hipotética - a probabilidade: a probabilidade envolve a defesa da imaginação crível contra o incrível. Decerto é por isto que Aristóteles escreve que uma impossibilidade convincente na mimese é sempre preferível a uma possibilidade inconvincente. $O$ peso real recai imediatamente não sobre a simples verossimilhança ou a referência (visto que Aristóteles reconhece que um artista pode representar algo que é fisicamente impossível), e sim sobre a persuasão mimética: a tarefa do artista é nos convencer de que aquilo podia ter acontecido. Assim a plausibilidade e a coerência interna se tornam mais importantes do que a exatidão referencial. E esta tarefa, naturalmente, demandará um grande artifício ficcional, e não um mero registro informativo (WOOD, 2011, p. 12; grifos em itálico são do autor, em negrito são meus). 
Esta plausibilidade hipotética, que é a probabilidade, coloca-nos exatamente diante daquilo que nós, pesquisadores, fazemos no nosso cotidiano de pesquisa com nossos objetos. Nós os observamos, descrevemos, mas fundamentalmente os indagamos a partir do nosso próprio arsenal reflexivo e nossas ferramentas. A metodologia, nos ensina a também socióloga Maria Cecília Minayo, inclui as concepções teóricas de abordagem, o conjunto de técnicas que possibilitam a apreensão da realidade e também o potencial criativo do pesquisador (1994). Nós também, a partir dos elementos que, meticulosamente, coletamos, realizamos contínuas "viagens imaginárias", ensaiando hipóteses, experimentando probabilidades, construindo "castelos no ar", confeccionando, como um artesão, suas próprias ferramentas e seu artesanato. É dessa forma que o sociólogo Charles Wright Mills denomina o nosso fazer: "artesanato intelectual" (2009), pois o trabalho intelectual está sempre inserido num tempo e lugar e não está separado da nossa vida.

Wright Mills defende que o "potencial criativo" é parte do que denomina "imaginação sociológica", que consiste na capacidade pessoal do pesquisador de fazer, das preocupações sociais, questões públicas e indagações perscrutadoras da realidade. A "imaginação sociológica" "[...] é uma qualidade de espírito que thes ajude a usar a informação e a desenvolver a razão, a fim de perceber, com lucidez, o que está ocorrendo no mundo e o que pode estar acontecendo dentro deles mesmos" (1980, p.11).

O que se apresenta aqui é, portanto, o que denominamos capacidade criadora e experiência do pesquisador, este tempo de amadurecimento e de ruminação que nos auxilia a ampliar nossos horizontes reflexivos, a ensaiar a plausibilidade hipotética do nosso saber, auxilia na visualização dos vários pedaços do seu material e que, em certo momento, você os conecta. Verdadeiro "artesanato intelectual", na acepção de Wright Mills, pois as ideias são subprodutos da vida cotidiana e não figuram num mundo além. As partes, reitera Sokolovski no seu livro Introdução à Fenomenologia,

[...] são somente compreendidas contra o fundo dos todos apropriados, que multiplicidades de aparências aportam identidades, e que ausências não fazem sentido exceto como (sic) jogadas contra as presenças que podem ser alcançadas por meio delas. A fenomenologia insiste que a identidade e a inteligibilidade estão disponíveis nas coisas, e que nós mesmos somos definidos como aqueles para os quais estas identidades e inteligibilidades são dadas. (Sokolovski, 2004, p. 12).

Resta-nos imaginar e fazer o que uma recente autora, pesquisadora no Trinity College em Cambridge, escreveu em seu primeiro livro 
publicado, Brigid Lowe. Perguntar se a ficção faz afirmações verdadeiras sobre o mundo é descabida, "porque a ficção não nos pede para acreditar nas coisas (num sentido filosófico), e sim para imaginá-las (num sentido artístico)".

\begin{abstract}
Imaginar o calor do sol nas costas é totalmente diferente de acreditar que amanhã vai fazer sol. Uma experiência é quase sensual, a outra é totalmente abstrata. Quando contamos uma história, mesmo querendo ensinar uma lição, nosso objetivo primário é gerar uma experiência imaginativa (apud Wood, 2011, p. 203).
\end{abstract}

Temos que ter claro, infelizmente, como diz Maurice Blanchot, que "[...] a obra de ficção nada tem a ver com honestidade: ela trapaceia e só existe trapaceando" (1997, p. 187). É um eterno engodo. "Sua realidade, continua ele, é o deslizamento entre o que é e o que não é, sua verdade, um pacto com a ilusão. Ela mostra e retira; vai a algum lugar e deixa crer que o ignora. É no modo imaginário que encontra o real, é pela ficção que se aproxima da verdade" (1997, p. 187, grifos meus).

Isto não transforma textos como $A$ Metamorfose de Kafka e A Fome de Knut Hansum, por exemplo, em menos aflitivos e verdadeiros. Nos emocionamos com o imaginário produzido pela literatura não porque os tomamos erroneamente por realidades, afirmava Samuel Johnson, um grande especialista em Shakespeare, mas porque esta "representações" trazem realidades à nossa mente (apud Wood, 2011, p. 204). A arte, para George Eliot, pseudônimo da romancista Mary Ann Evans que viveu no século XIX, "é a coisa mais próxima da vida; é um modo de aumentar a experiência e ampliar nosso contato com os semelhantes para além do nosso destino pessoal" (apud Wood, 2011, p. 205).

Se eu sou eu e meus arredores, meu imaginário é parte constitutiva deste meu mundo e disto que sou. A significação que constituímos é resultado desta interação, que conecta homem e mundo no processo de construção de sentidos. O social, desta forma, se produz através de uma verdadeira rede de sentidos, de marcos de referência, que também são simbólicos, através dos quais os homens se comunicam, criam uma identidade coletiva e designam o seu lugar frente às instituições de poder desta dada sociedade. Através de suas representações ideológicas, exprimem seus desejos e aspirações, justificam seus objetivos, concebem o passado como o desejam

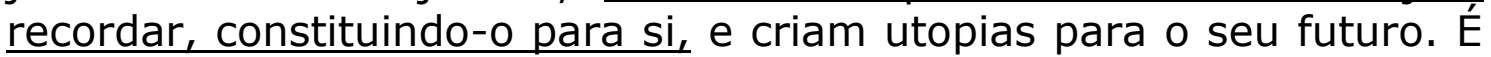
assim que constituímos o passado que desejamos recordar e onde as coisas ganham a espessura que passamos a lhes atribuir transformando e assimilando o passado e o heterogêneo, permitindonos cicatrizar nossas feridas, reparar nossas perdas, reconstituir forças perdidas, inventar e reinventar, a partir daí, futuros possíveis, 
como uma narrativa que deve ser continuamente repetida para não nos perdermos de nós mesmos.

No mundo real, diz Simone de Beauvoir,

[...] o sentido de um objeto não é um conceito apreensível pelo entendimento puro: é o objeto enquanto se nos desvela na relação global que mantemos com ele e que é ação, emoção, sentimento; pede-se aos romancistas para evocarem essa presença de carne e osso cujo complexidade, cuja riqueza singular e infinita, ultrapassa qualquer interpretação subjetiva. [...] subjugado pela história que Ihe é contada, o leitor reage aqui como perante os acontecimentos vividos. Comove-se, aprova, indigna-se, por um movimento de todo o seu ser, antes de formular juízos que arranca de si mesmo sem que tenhamos a presunção de Ihos ditarmos. É isso que confere valor a um bom romance. Ele permite efetuar experiências tão completas, tão inquietantes como as experiências vividas (1965, p. 81).

Ao falar sobre os "arredores", Sartre se utiliza de noções como adversidade e utensilidade, noções estas que dependem inteiramente do projeto pessoal, pois as mudanças que vivencio são captadas por mim como motivos para abandonar ou seguir em frente, à luz deste meu projeto existencial. O exemplo de Sartre é esclarecedor: ele diz que quer chegar à cidade vizinha de bicicleta o mais rápido possível. Ora, isso subentende o tal projeto pessoal: o lugar onde estou, a distância a ser percorrida e a livre adaptação dos meios (esforços) para que eu possa alcançar este fim. Mas, neste percurso, fura um pneu da minha bicicleta, o sol está muito forte, o vento sopra de frente, etc., e nada disto eu havia previsto. São os arredores e sem dúvida, afirma ele, se manifestam no e pelo meu projeto principal: assim, o pneu furado é somente um transtorno ou um impedimento; o vento se apresentará como vento ou como uma barreira pesada demais para ser atravessada por mim neste percurso; não se pode negar, que o sol esteja quente, mas sou eu que designo aquilo que me é suportável e insuportável, sou eu que crio estratégias para lidar com a adversidade.

A realidade é constituída por sujeitos que fabulam, representam, simbolizam o real e o possível (TEVES, 1992, p. 7). Os "fatos", as adversidades, os "arredores", fazem parte da estrutura da situação; nós "topamos" com eles continuamente, mas eles sempre são fatos para alguém que Ihes atribui significações. Isto significa dizer que prolongamos nossa subjetividade nos fatos e nos projetamos ininterruptamente nesse mundo aparentemente dado e imutável. Neste sentido, os fatos são sempre trabalhados pela significação e o sujeito encontra-se situado na corrente da história em meio ao prático-inerte. Isto significa também que, tanto a Literatura como a Ciência, são fatos atravessados pela subjetividade. Ao mesmo tempo, 
este mundo duro e opaco é constituído significativamente a partir de expectativas e possibilidades, a partir de plausibilidades hipotéticas que cada um de nós projeta em torno de si. Mas vivemos em tempos de rendição da liberdade às determinações, diz Franklin Leopoldo e Silva (2008), uma submissão cega à dimensão objetiva do mundo. Se somos livres e determinados, estamos reduzindo esta relação dialética exclusivamente a um de seus polos, deixando-nos constituir pela exterioridade objetiva. Há uma simplificação e banalização da experiência, como já bem afirmava Marcuse em seu Ideologia da Sociedade Industrial (1967). Trata-se de um paradoxo extremamente revelador, indica Franklin Leopoldo e Silva,

[...] para quem desejar fazer um diagnóstico da contemporaneidade: a experiência banalizada é aquela que se caracteriza pela renúncia do sujeito a participar ativamente das transformações de sua própria história e do fluxo mais íntimo de sua própria temporalidade. Neste sentido se pode dizer que as possibilidades emancipadoras de um mundo em mutação se dissolvem no frenesi alienante da vivência absolutamente externa e completamente impessoal da rotina as transformações, com a qual o indivíduo convive no modo de um consumo indiferente do que é sempre novo e sempre igual". (2008, p. 161-162).

Rosa Monteiro, escritora espanhola, em seu livro intitulado $A$ louca da Casa (2004), expressão usada por Santa Tereza de Jesus para se referir à Imaginação, diz que "escrevemos na escuridão, sem mapas, sem bússolas, sem sinais reconhecíveis do caminho. Escrever é flutuar no vazio" (p.72). Talvez ela tenha razão. Se alguns de vocês já esteve diante desta experiência, entendem bem o que ela está dizendo. Entenderão também que "[...] Um pensamento independente é um lugar solitário e ventoso" (p. 44) e que diariamente topamos com palavras, frases, poesias "[...] que nos surpreendem com sua verdade, que nos comovem e nos sustentam, que abalam o edifício do hábito até os alicerces" (WOOD, 2011, p. 122).

Gostaria de finalizar com uma frase do poeta inglês John Donne citada por Ernesto Sabato, que dizia que:

"[...] ninguém dorme na carreta que o conduz do cárcere ao patíbulo e que, no entanto, ou todos dormimos desde a matriz até a sepultura, ou não estamos inteiramente despertos.

Uma das missões da grande literatura: despertar o homem que viaja rumo ao patíbulo" (2011, p.25). 


\section{Considerações finais}

Apesar de não ser comum, entre psicólogos, nem a abordagem de questões como as que aqui destacamos, nem a referência a Sartre como interlocutor para tais discussões, acreditamos que este é um caminho prolífico para a Psicologia. Um dos objetivos finais deste artigo, foi o de indicar as possibilidades de trabalho com o referencial sartriano e dar destaque a temas que são pouco usuais na Psicologia mas que são fundamentais para os estudos sobre a subjetividade, sobre as relações que a atravessam e sobre como tudo isto está conectado ao mundo social no qual vivemos.

A partir deste artigo nos foi possível indicar caminhos plausíveis para uma Psicologia carente de renovação teórica e de articulação interdisciplinar. Partimos, nesse sentido, de dois pontos comuns - a psicologia e o existencialismo sartriano - e indicamos, a partir desses, três direções possíveis, quais sejam: a ciência política visto pela critica sartriana à noção de liberdade; o mundo do trabalho, compreendido enquanto crescimento da alienação e da serialidade; e, por fim, o imaginário como criação e a necessidade epistemológica de integrá-lo no campo cientifico da Psicologia.

Tais diferentes possibilidades representam ao mesmo tempo, no nosso ponto de vista, a riqueza que o pensamento de Sartre representa enquanto instrumento teórico e metodológico para refletir criticamente sobre o homem e a ciência do homem na contemporaneidade, bem como uma certa unidade de nossas reflexões. Uma riqueza que nos permite renovar, como já dito, o pensar psicológico com noções que, ao se oporem ao conceitos positivitas herdados das ciências da natureza, nos oferecem novas compreensões do homem enraizado em seu processo histórico, como sujeito implicado com o mundo social. Uma renovação da psicologia que reivindica uma liberdade situada em e oposição à da tradição liberal, que critica as novas formas de gestão e organização do trabalho como reprodução do inumano e que busca superar a ontologia ingênua do real-irreal, típica do naturalismo positivista, e para recolocar o papel fundamental do homem como agente de criação. Perspectivas essas que, ao mesmo tempo, ao mostrarem diferentes e profícuos caminhos para uma renovação do campo psicológico ou ainda mais precisamente, para um repensar o campo das ciências do homem em seu conjunto, mostram também uma unidade no que diz respeito a um ponto fundamental: a liberdade como fundamento inalienável dos valores, da vida em comum e da criação histórica. 


\section{Referências}

ANDRADE, C. D. Corpo. Rio de Janeiro: Record, 1984.

ANTUNES, R. Os sentidos do trabalho. São Paulo, Boitempo, 1999. ARENDT, H. Entre o passado e o futuro. São Paulo: Perspectiva, 1972.

BARATA, A. Liberdade e má-fé. In: ALVES, P.; SANTOS, J. M.; FRANCO DE SÁ, A. Humano e inumano. Lisboa: Phainomenon, 2005.

BEAUVOIR, S. de. Literatura e Metafísica. In: __ o existencialismo e a sabedoria das nações. Porto: Minotauro, 1965, p. 79-95.

BERLIN, I. Dois conceitos de liberdade. In: BERLIN, I.; HARDY, H.; HAUSHEER, R. (Eds.). Estudos sobre a humanidade: uma antologia de ensaios / Isaiah Berlin. São Paulo: Companhia das Letras, 2002.

BLANCHOT, M. A parte do fogo. Rio de Janeiro: Rocco, 1997.

BOIA, L. Pour une histoire de I'imaginaire. Paris: Les Belles Lettres, 1998.

BOLTANSKI, L. \& Chiapello, E. Le nouvel esprit du capitalisme. Paris, Gallimard, 1999.

CASTRO, F. G. As transformações no mundo do trabalho na contemporaneidade $e$ as novas formas de subjetividade $e$ sofrimento: Uma investigação psicossocial sobre as formas atuais de sofrimento no trabalho e a emergência do suicídio como novo problema social. Projeto de pesquisa aprovado pelo Departamento de Psicologia Clinica, Instituto de Psicologia, UFRJ em maio de 2011. Disponível em: <http://lattes.cnpq.br/9580453990111289>. Acesso em: 21.08.2012.

Burnout, Projeto de ser e paradoxo organizacional. 2010. 408 f. Tese (Doutorado em Psicologia) - Programa de Pós Graduação em Psicologia, Universidade Federal de Santa Catarina, Florianópolis.

COLETTE, J. Existencialismo. Porto Alegre: L\&PM (Pocket), 2009.

CASEVECCHIE J. Lu, vu et entendu em Mai 68. Paris, Chéne, 2008. CASSIRER, E. A filosofia do iluminismo. Campinas: Editora da Unicamp, 1997.

CASTORIADIS, C. Figuras do impensável: encruzilhadas do labirinto vol. VI. Rio de Janeiro, Civilização brasileira, 2004.

. O mundo fragmentado: As encruzilhadas do labirinto III. São Paulo, Paz e terra, 1992.

- A ascensão da insignificância: As encruzilhadas do labirinto IV. São Paulo, Paz e terra, 2002.

CLOT, Y. Clinique de I'Activité et Psychologie Travail. In: Notas do Cours PST 106, Conservatoire national de artes et métiers - CNAM, Paris, março à junho de 2010. 
CONSTANT, B. Da liberdade dos antigos comparada à dos modernos. Revista Filosofia Politica, São Paulo, v. 2, 1985.

DEJOURS, C. \& BÈGUE, F. Suicide et travail: que faire! Paris, Puf, 2009.

DUJARIER, M-A. L'idéel au travail. Paris, Puf,2006.

EWALD, A. P. Cabeceios, cochilos e esquecimentos: possível articulação entre subjetividade, arte e psicologia social fenomenológica. In: MELO, W.; FERREIRA, A. P. A sabedoria que a gente não sabe. Rio de Janeiro; São João del Rei: Espaço Artaud; UFSJ, 2011, p. 33-54.

- Subjetividade e literatura: harmonias e contrastes na interpretação da vida. Rio de Janeiro: NAU, 2011.

- O real e o irreal no desvio da razão: imaginário e fenomenologia existencialista. (UERJ, Ed.) Cadernos de Psicologia, Rio de Janeiro, v. 1, n. 6, p. 27-38, 1996.

GAULEJAC. V. La société malade de la gestion. Paris, Seuil, 2009. GAULEJAC, V.; LEONETTI, I. La lutte des places. Paris: Desclée de Brouwer, 1994.

HARVEY, D. A condição pós-moderna. São Paulo: Atlas, 1992.

HEGEL, G.W.F. Fenomenologia del espiritu. Mexico, Fondo de Cultura Economica, 1987 [1807].

KOLM, S.-C. Le liberalisme moderne. Paris: Presses Universitaires de France, 1984.

KOJĖVE, A. Introdução à leitura de Hegel. Rio de Janeiro, Ed.UERJ/Contraponto, 2002.

Le GOFF, J-P. La barbarie douce: la modernisation aveugle des entreprise et de la école. Paris, La Decouvert, 1999.

LINHART, D. La modernisation de la entreprise. Paris, La Decouvert, 2004.

MANZANO, T. R. Artimanhas da ficção. Ensaios de literatura. São Paulo: Terceiro Nome, 2008.

MARCUSE, H. A ideologia da sociedade Industrial. Rio de Janeiro: Zahar, 1967.

MERQUIOR, J. G. O liberalismo - antigo e moderno. Rio de Janeiro: Nova Fronteira, 1991.

MILLS, C. W. A imaginação sociológica. Rio de Janeiro: Zahar, 1980.

Sobre o artesanato intelectual e outros ensaios. Rio de Janeiro: Jorge Zahar, 2009.

MINAYO, M. C. O desafio do conhecimento. São Paulo, Rio de Janeiro: Hucitec, Abrasco, 1994.

MOREIRA, P.; PROLONGEUAU, H. Travailler à em mourrir: quand le mond de l'entreprise méne au suicide. Paris, Flammarion, 2009.

PESAVENTO, S. J. 500 anos de América: imaginário e utopia. Porto Alegre: UFRGS, 1992. 
PESAVENTO, S. J. O imaginário da cidade. Porto Alegre: UFRGS, 1999.

PIVERT, I. Soleil capitaliste: entretiens au coeur des multinationales. Paris, Sextan, 2009.

POUGET, M. Taylor et le taylorisme. Paris, Colection "Que sais-je!", 2008.

SABATO, E. O escritor e seus fantasmas. São Paulo: Companhia das Letras, 2011.

SARTRE, J.-P. A imaginação [1936]. São Paulo - Rio de Janeiro: DIFEL, 1980.

. O imaginário. Psicologia Fenomenológica da Imaginação. São Paulo: Ática, 1996.

O Ser e o nada. Ensaio de ontologia fenomenológica (15a Edição). (P. Perdigão, Trad.) Petrópolis, RJ: Vozes, 2007.

. La critique de la raison dialectique, tome. 1 . Théorie des ensembles pratiques. Paris, Gallimard. 1985.

SILVA, F. L. Descontrole do tempo histórico e banalização da experiência. In: NOVAES, A. Mutações: ensaios sobre as novas configurações do mundo. Rio de Janeiro; São Paulo: Agir; SESCSP, 2008. (pp. 149-161)

SIMONT, J. Jean-Paul Sartre: Un demi-siècle de liberté, De Boeck, Bruxeles, 1998.

SOKOLOVSKI, R. Introdução à fenomenologia. São Paulo: Loyola, 2004.

TEVES, N. O imaginário na configuração da realidade social. In: Imaginário social e educação. Rio de Janeiro: UFRJ, 1992, p. 3-33.

TRAGTEMBERG, M. (2006). Burocracia e ideologia. São Paulo, Unesp.

WOOD, J. Como funciona a ficção. São Paulo: CosacNaify, 2011.

ZOLA, E. Como se casa. Como se morre. São Paulo: Ed. 34, 1999. . O Romance experimental e o naturalismo no Teatro.

São Paulo: Perspectiva, 1982.

Endereço para correspondência

Amana Rocha Mattos

Instituto de Psicologia - UERJ

Rua São Francisco Xavier, $524-10^{\circ}$ andar.

Rio de Janeiro - RJ

Endereço eletrônico: amanamattos@gmail.com

Ariane Patrícia Ewald

Instituto de Psicologia - UERJ

Rua São Francisco Xavier, $524-10^{\circ}$ andar.

Rio de Janeiro - RJ

Endereço eletrônico: arianeuerj@yahoo.com.br

Fernando Gastal de Castro

Av. Pasteur, 250, Pavilhão Nilton Campus, Praia Vermelha, RJ. 
CEP: $22290-140$

Endereço eletrônico: fernandogastal@gmail.com

Recebido em: 09/12/2012

Reformulado em: 16/06/2012

Aceito para publicação em: 21/06/2012

Acompanhamento do processo editorial: Ana Maria Lopez Calvo de Feijoo

\section{Notas}

*Professora Adjunta do Instituto de Psicologia da Universidade do Estado do Rio de Janeiro, Brasil; doutora em Psicologia.

**Professora Adjunta do Instituto de Psicologia e do Programa de Pós-Graduação em Psicologia Social da Universidade do Estado do Rio de Janeiro, Brasil; doutora em Comunicação e Cultura.

***Professor Adjunto do Instituto de Psicologia da Universidade Federal do Rio de Janeiro, Brasil; doutorado em Psicologia.

${ }^{1}$ Definição proposta por V. De Gaulejac, \& I. Leonetti no livro "La lutte des places" e que defini o tecido social da sociedade contemporânea por uma luta individualiza e competitiva por postos de trabalho e contra a exclusão em substituição à luta social entre classes ocorrida até meados da década de setenta na Europa ocidental.

${ }^{2}$ História relatada no livro de Paul Moreira e Hubert Prolongeau "Travailler à en mourrir: quand le monde de la entreprise mène au suicide" op, cit.

${ }^{3}$ Utilizo aqui a noção, já consagrada, do sociólogo Charles Writgh Mills em seu livro Sobre o Artesanato Intelectual e outros ensaios (2009).

${ }^{4}$ Ver, especialmente, o trabalho de Lucian Boia, Pour une histoire de l'imaginaire, que fornece um amplo panorama crítico das perspectivas relacionadas ao imaginário. Confrontar também com o capítulo de Evelyne Patlagean (1993), como também com os trabalhos de Sandra Jatahy Pesavento (1992 e 1999).

5"Resposta à pergunta: 'Que é Esclarecimento?'", de Immanuel Kant, é um texto de 1783 no qual ele responde a pergunta: "que é esclarecimento?", desafio lançado por um jornal. Neste texto ele aponta para dois conceitos caros ao existencialismo sartriano: autonomia e liberdade. É importante lembrar que o sentido de "esclarecimento" vem do verbo esclarecer, de uso cotidiano, como quando você esclarece a alguém, por exemplo, como chegar a um lugar específico; apontar caminhos, direções e sentidos. Logo no início do texto, Kant situa o "esclarecimento" como maioridade, isto é, como busca, por parte do indivíduo, de tirar suas dúvidas e tomar decisões a partir do esclarecimento delas; isto é, esclarecer para poder melhor escolher. Em contraposição à maioridade, ele usa o termo menoridade, para designar o conformismo, aquele indivíduo que por preguiça ou covardia no uso da reflexão, deixa que os outros decidam sua vida e até seus pensamentos.

${ }^{6}$ Este poema de Drumond foi originalmente publicado no livro Corpo (1984, p.41). Mas Drummond deu nova versão à ele, fazendo algumas mudanças no poema e no título, que se chamou "A verdade dividida", publicado em Contos Plausíveis. Informação retirada do site Memória Viva, disponível em: <http://memoriaviva.digi.com.br/drummond/poema072.htm>. Acesso em: 20 nov. 2005. 